\title{
EFFECTIVENESS OF DECISION SUPPORT SYSTEMS
}

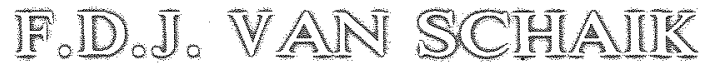

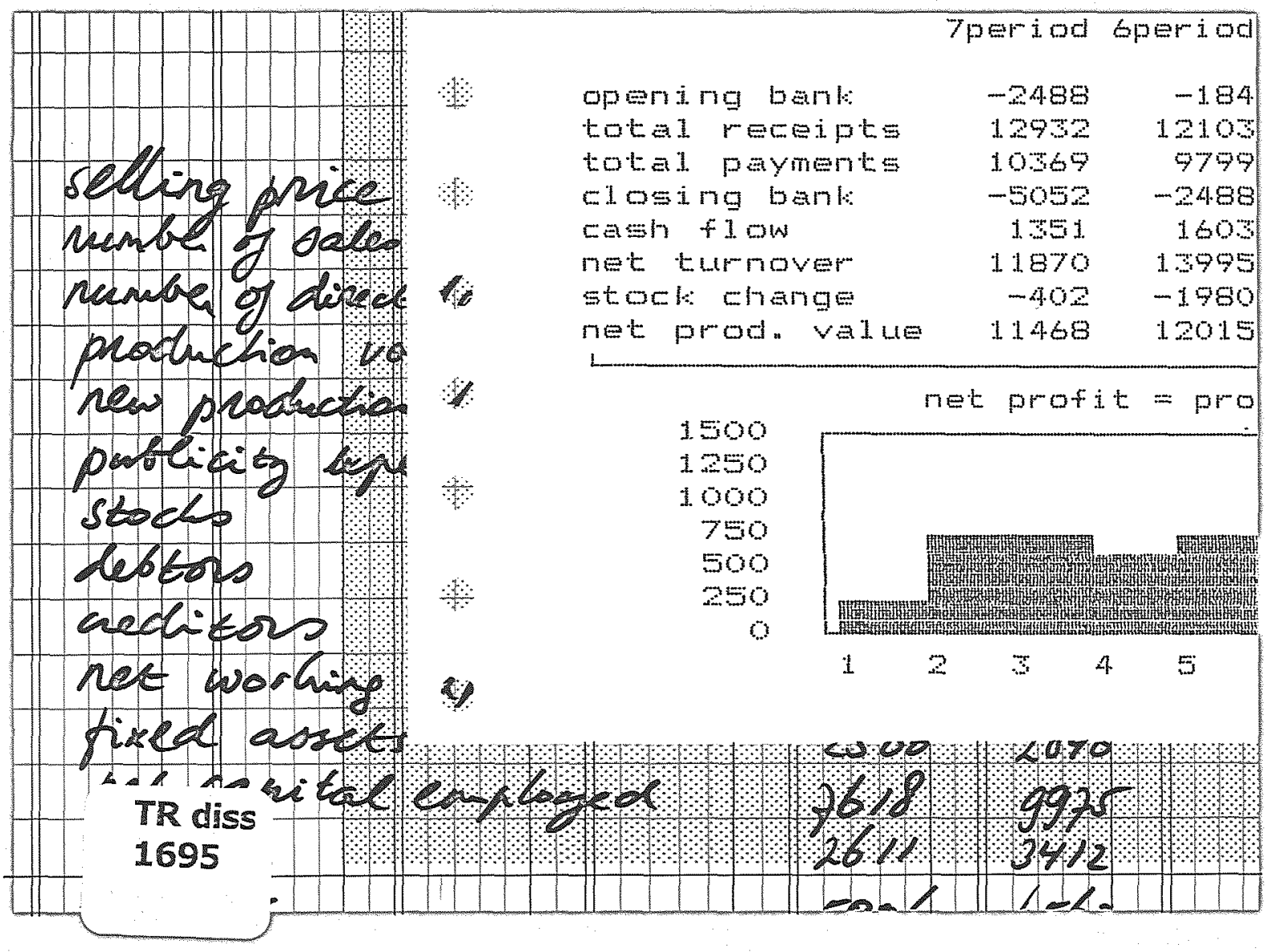




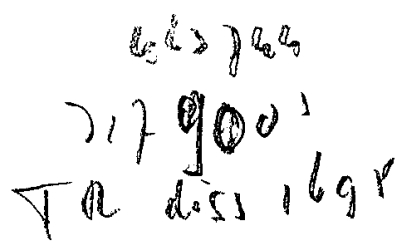

EFFECTIVENESS OF DECISION SUPPORT SYSTEMS 


\section{EFFECTIVENESS OF DECISION SUPPORT SYSTEMS}

\section{PROEFSCHRIFT}

ter verkrijging van de graad van doctor aan de Technische Universiteit Delft, op gezag van de Rector Magnificus,

Prof. Drs. P.A. Schenck, in het openbaar te verdedigen ten overstaan van een commissie door het College van Dekanen daartoe aangewezen, op dinsdag 20 december 1988 te 16.00 uur

door

\section{FRANÇOIS DIGNUS JOHANNES VAN SCHAIK}

\section{registeraccountant,} geboren te Yerseke

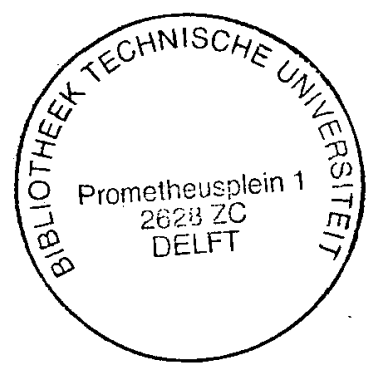

Delft University Press / 1988 
Dit proefschrift is goedgekeurd door de promotor:

Prof. Dr. H.G. Sol

\section{Promotiecommissie}

Prof. Dr. H.G. Sol, promotor

Prof. Dr. A. Bosman

Prof. Drs. B.K. Brussaard

Prof. Dr. Ir. J.J.M. Evers

Prof. Dr. J.P.C. Kleijnen

Prof. Ir. D.H. Wolbers 
to my parents, who never gave less than their best

to my brother Jan, who set the example

to my sister Anneke, who is the sunshine of my life 
Published and distributed by:

Delft University Press

Stevinweg 1

2628 CN Delft

The Netherlands

Telephone 015-783254

Cover:

Ir. Hans F. Ringnalda

CIP-DATA, Koninklijke Bibliotheek, The Hague

ISBN: 90-6275-515-1

(C) 1988 by F.D.J. van Schaik

All rights reserved. No part of this publication may be reproduced, stored in a retrieval system, or transmitted, in any form or by any means, electronic, mechanical, photocopying, recording or otherwise, without written permission of the publisher. 


\section{Contents}

1. Decision Support Environments 1

1.1 Introduction 1

1.2 Decision-Making Literature 4

1.3 Decision Support Systems Literature 18

2. Gaming 41

2.1 Gaming Literature $\quad 41$

2.2 Problem Statement 60

3. Approach 65

3.1 A Game 65

3.2 A Decision Support System 75

3.3 A Decision Strategy 86

3.4 Experimental Design and Treatments 92

3.5 Subject Population 98

3.6 Procedures 100

3.7 Independent and Dependent Variables 103

4. Analysis of the Experimental Data 111

5. Summary and Conclusions 127

5.1 Summary of Findings $\quad 127$

5.2 Limitations $\quad 129$

5.5 Future Research 130

$\begin{array}{ll}\text { References } & 133\end{array}$

Samenvatting in het Nederlands 151

Dankwoord 155

Curriculum Vitae 157

$\begin{array}{ll}\text { Index } & 158\end{array}$ 


\section{DECISION SUPPORT ENVIRONMENTS}

\subsection{Introduction}

Decision support systems have gained dramatically in popularity during the last decade. The research effort spent on decisionmaking and decision support systems has increased likewise, see McLean and Sol [1986].

Currently available decision support systems provide support primarily for well-structured problems. Attention is paid primarily to the Choice phase of the decision-making process as described by Simon [1960]. However, many authors have stressed the importance of supporting the Intelligence and Design phase when solving ill-structured problems.

Sprague [1986] observes that much of the research efforts in information systems has been devoted to supporting wellstructured, predominantly clerical work. He proposes to direct research interest towards supporting ill-structured problems in which structuring the problem situation is a crucial part of the decision-making process.

Keen [1987] lists as one of the priorities for research in the decision support systems field the measurement of effectiveness and quality of decision-making in ill-structured problem situations. 
Bosman [1986] states that decision-makers, because of their cognitive constraints, are apt to divide an ill-structured problem into more easily solvable parts. However, they need instruments to assist them in structuring the problem into subproblems, in order to prevent finding solutions that are sub-optimal.

Sol [1982] states that for an inquiry into the effective use of computers for solving ill-structured problems, we should not focus on the heuristics for finding a solution. Rather, we should reveal the paths along which a problem should be specified, a set of action alternatives should be created, and a solution should be arrived at.

Attempts at supporting decision-making in ill-structured problem situations have focused on the development of decision support systems. In our research we investigate whether these systems in fact improve decision-making. A different way of supporting the decision-maker is structuring his problem, by giving him a so-called decision strategy: a sequence of steps to take in the decision-making process.

Our study deals with the question: How effective are a decision support system and a decision strategy?

As a guide to the reader, we give a brief summary of the contents and organization of this study.

In order to put the problem statement into perspective, we first give an overview of the research literature on decisionmaking in section 1.2 and on decision support systems in section 1.3 . 
Chapter 2 consists of two sections. Section 2.1 provides background information on the gaming approach to information systems research. Gaming is compared to other research approaches, a system-theoretical basis is given for the gaming approach, and a number of gaming-experiments related to our research questions are examined. Section 2.2 details the research questions, the specific hypotheses and discusses their rationale.

Chapter 3 contains the details of the research approach we follow in this study. First we describe the game, the decision support system, and the decision strategy. Next we go into the technicalities of the experiment: the experimental design, the treatments, the subject population and the procedures. In the final section of chapter 3 the independent and dependent variables in the experiment are defined.

In chapter 4 we look into the results of the series of experiments and we apply statistical analysis to test the hypotheses formulated.

Finally, chapter 5 contains the implications, limitations and significance of the research outcomes. 


\subsection{Decision-Making Literature}

In this section we give a review of decision-making literature in order to lay the foundations from which the rationale for our study, the statement of our problem and the design of our research problem emerge.

We start with defining the notions of decision-making and of a problem. Decision-making is solving a problem. A plethora of definitions of the word problem has been given in the literature. We define a problem in the same way as Sol [1982] does. A problem is said to exist if the following conditions are met:

someone is in doubt as to which choice is best to remove his dissatisfaction with his present state, where he can identify:

- one or more outcomes that he desires,

- two or more unequally efficient or effective courses of action, and

- an environment containing factors that affect the outcomes. We call that someone a decision-maker.

One vision on a decision-maker is that he behaves in an objectively rational way. The decision-maker tries to find the optimal course of action and has all relevant information for his decision readily available. In this vision, the decision-maker is pictured as a homo economicus. This vision on the decisionmaker used to be a matter of course for researchers of decision-making. Until Simon [1960] wrote his now famous book "The New Science of Management Decision", this vision was an implicit assumption of any theory on improving decision-making. 
Bosman [1977] summarizes the critique on the vision of the decision-maker as a homo economicus. He states that decisionmakers usually do not have all relevant information when making decisions. Collecting and checking information cost both time and money. A decision-maker usually stops looking for more information, as soon as he feels comfortable with the information he has. At that point he does not think that yet more information will lead to yet better decisions. Even if all relevant information were available to the decision-maker, he would in most cases be unable to process all that information. Human beings are constrained by a cognitive limitation: the memory and computing power of a human being is too limited to process huge amounts of information. Because of this limitation the decision-maker is not always able to apply socalled analytic procedures, i.e. procedures that guarantee an optimal solution. He often has to resort to so-called heuristic procedures, i.e. procedures that lead to a solution that is not necessarily optimal.

Simon [1960] calls the two paradigms for decision-making that he distinguishes the objective rationality and the procedural rationality. We prefer to call the latter bounded rationality, since the word procedure already has so many meanings, see also Sol [1982, p. 7]. This paradigm of bounded rationality means that the decision-maker looks for a course of action, which he thinks is good enough. He searches for a satisficing alternative, rather than an optimal alternative. The view that a decision-maker does not necessarily search for the best alternative, but looks for an alternative that is good enough, has been one of Simon's most valuable contributions to the study of decision-making. 
We regard decision-making as identical to problem-solving. It involves a process, in which we can distinguish a number of phases. We call this the decision-making process or problemsolving process. We define a decision-making process as a set of activities that begins with the identification of a dissatisfaction with the present state and ends with the solution.

Many models of the decision-making process have been proposed in the literature.

Witte [1972] addressed the issue of whether phases do exist and whether they follow a simple sequence as suggested in most of the literature. He investigated 223 decision-making processes and found that decision-making processes can be delineated in distinct phases, but he also found that there is no simple sequential relationship between them.

Now, we will examine a number of models that have been proposed by various authors to describe the decision-making process. They all have one characteristic in common: they break up the decision-making process into a number of phases or steps.

Simon [1960] cites an early decision-making process model, developed by Dewey [1910, chapter 8]. He states that decisionmaking means answering the following three consecutive questions:

1. What is the problem?

2. What alternatives are available?

3. Which alternative is best?

This model is slightly modified by Simon [1960]. He distinguishes three phases: 
1. The Intelligence or information gathering phase, which involves scanning the environment for situations demanding a decision.

2. The Design or brainstorming phase, which deals with generating, developing and analyzing possible alternative courses of action.

3. The Choice phase, which means selecting one of the alternative courses of action.

The most striking difference between Dewey's and Simon's model lies in the third phase. Simon just calls this phase: Choice, while Dewey calls this phase choosing the best alternative. Dewey implies that choice means asking the question: What is the best alternative? This difference reflects the two paradigms of the decision-maker described above. Simon recognizes the fact that loops exist in his model. Decision-making does not mean going through three consecutive phases, without ever going back to an earlier phase.

The three-phases model developed by Simon has become famous and is quoted widely. Many authors depict the decision-making process in much the same way as Simon does.

Some authors, like Sprague and Carlson, regard the Implementation of the solution as part of the Choice phase. Many other authors feel that implementation should be shown separately as a fourth phase. Simon [1960, p. 14], though, regards implementing or executing the decision as a whole new decision, again consisting of the three phases Intelligence, Design and Choice. A much encompassing decision creates a whole new situation for the management of the firm, requiring other decisions, as how to implement that decision. 
Bosman [1977] pictures this relationship between decisionmaking process, decision, implementation and results of the implementation as shown in exhibit 1-1.

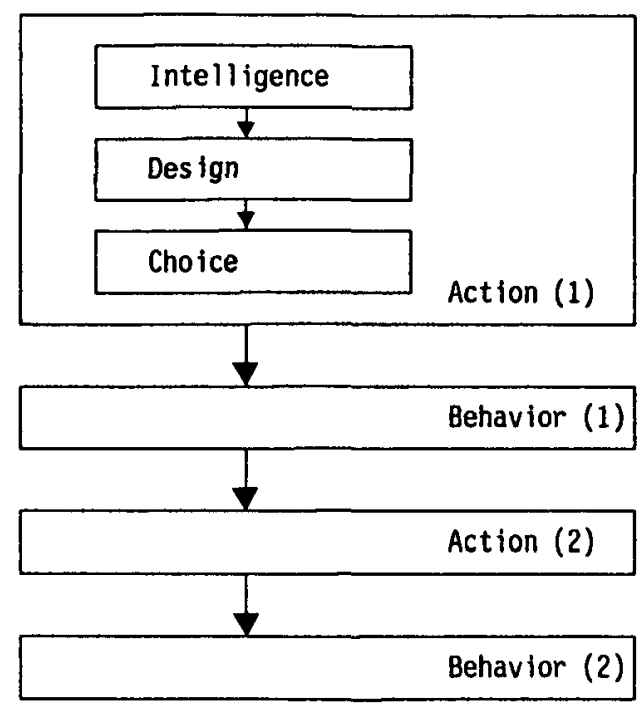

Exhibit 1-1. Bosman [1977]'s view on the relationship between action and behavior.

\section{Action (1)}

This notion refers to the process of decision-making. This process consists of the Intelligence-Design-Choice sequence according to Simon.

\section{Behavior (1)}

This notion describes the results of Action (1). Behavior (1) and decision are synonymous. 
Action (2)

This notion refers to the execution of the activities to implement the decision.

\section{Behavior (2)}

This notion is the description of the results of Action (2), for instance, a report, leading to feedback.

Einhorn and Hogart [1981] propose a model with four phases:

1. information acquisition

2. information evaluation

3. action

4. feedback/learning.

The first three phases of Einhorn and Hogarth's model are roughly comparable to Simon's three phases. Simon calls this fourth phase one of the loops within his model. He does not consider his three phase model as a one-way street.

Beach and Mitchell [1978] make a further breakdown of the decision-making process in a total of seven phases:

1. Problem recognition

2. Evaluation of task

3. Decision strategy selection

4. Information search

5. Information evaluation

6. Strategy implementation

7. Choice.

Their significant addition is the decision strategy selection. This phase comes when the problem has been identified. It involves deciding on what information will be gathered and how it will be evaluated. 
Sol [1982], following Mitroff et al. [1974], pictures the problemsolving process as shown in exhibit 1-2, leading to four products, with six activities linking these products. He distinguishes the following four products in a decision-making process: a problem as identified in the real system, a conceptual model, an empirical model and a solution. The activities are conceptualization, problem specification, solution finding, implementation, consistency check, and correspondence check. Next we describe the products and activities shortly.

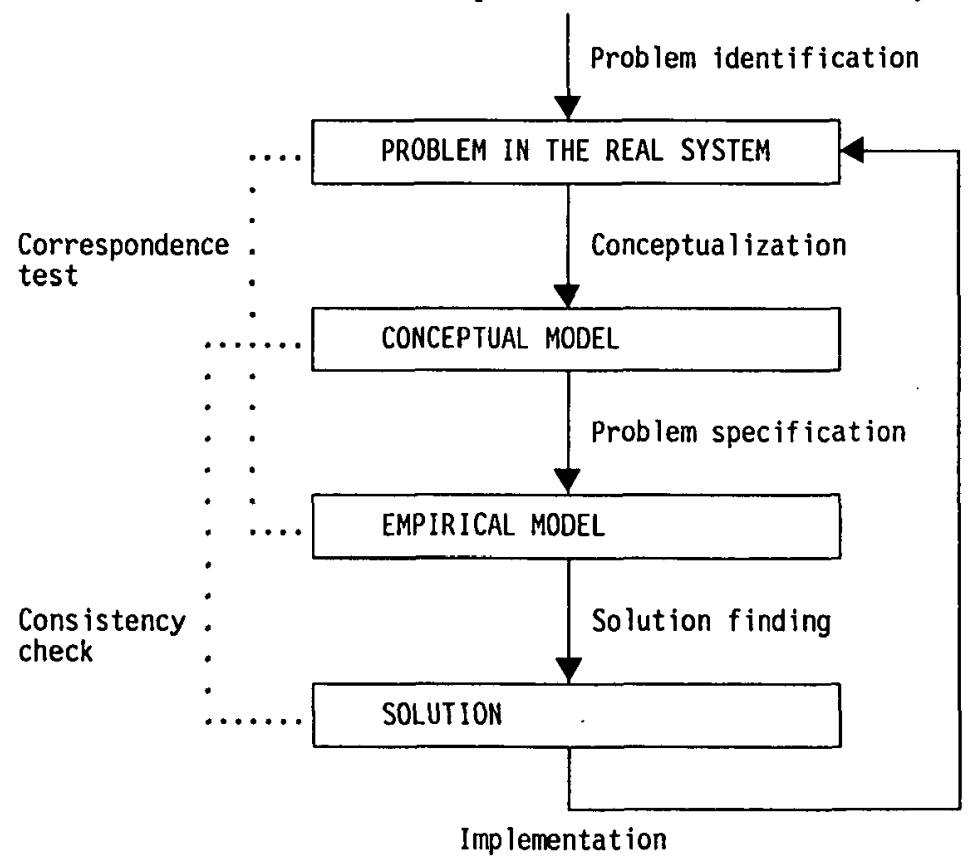

Exhibit 1-2. Decision-making process, according to Sol [1982]. 


\section{Problem in the real system}

Starting point is a problem that exists in the real system and that has been identified as such.

\section{Conceptualization}

In this activity the decision-maker, who is faced with a problem that he has already identified, tries to establish what is relevant and what is not relevant to his problem. He makes this distinction with some idea in mind, i.e. he does this with interest for some aspects of the problem and disregard for other aspects. We call the personal inclination to look at some aspects of a problem a Weltanschauung or a paradigm.

\section{Conceptual model}

This is the model that the problem solver has made of the problem. This is what he thinks is the problem in the real system. It is called conceptual model, since it is the concept, the image, that the decision-maker has of the real system.

\section{Problem specification}

From the conceptual model the decision-maker develops the empirical model. This means he collects data and enters these into the model. The initial results may lead him to specify the problem in a different way. After some iterations he arrives at the empirical model.

\section{Empirical model}

This is the model that corresponds as closely as possible with the problem in the real system. This model is called empirical model, since it is filled with empirical data and can be empirically tested. The specification of the problem 
is complete to the extent that the decision-maker thinks is relevant.

\section{Correspondence test}

This is the test whether the empirical model indeed corresponds with the problem in the real system.

\section{Solution finding}

Once the problem is specified in the empirical model, this model can be used to generate and evaluate alternative courses of action. Solution finding means choosing one of these courses of action.

\section{Solution}

This is the course of action, chosen from the courses of action considered. It is chosen, maybe because it is the best course available, maybe because that course was the first to be found and happened to be good enough.

\section{Consistency check}

In this activity the decision-maker checks whether the solution he found is actually consistent with the conceptual model.

\section{Implementation}

Once a solution is found, a course of action is implemented. This implementation influences the problem situation.

There are different types of problems, and according to Simon, the type of problem determines which phase of the decisionmaking process should be emphasized. For some types of problem some phases of the decision-making process are more important than others. In other words, depending on which 
category of problems we are dealing with, an appropriate emphasis on phases of the decision-making process is required.

Several taxonomies of problems have been developed. The most widely quoted taxonomy is the one that categorizes problems as either well-structured or ill-structured. These categories were first developed by Simon, but not under those names; he called them programmed and non-programmed problems. The terms well-structured and ill-structured have become better known, because they imply less dependence on the computer and relate more directly to the basic nature of the problem-solving activities in question. Many definitions of structuredness of a problem are given in the literature, see Newell [1969, p. 360], Slagle [1971], Nilsson [1971] and Uhr [1973].

Following Sol [1982], we define a problem as well-structured if the following conditions are met:

- the set of alternative courses of actions or solutions is finite and limited,

- the solutions are consistently derived from an empirical model that shows a good correspondence,

- the outcome of the courses of action can be numerically evaluated.

Problems that do not fulfil these requirements, are defined as being ill-structured.

According to Simon [1960], ill-structured problems require more emphasis on the Intelligence and Design phase of the decision-making process, while well-structured problems require more emphasis on the Choice phase. He observes that researchers have paid little attention to ill-structured problems, concentrating instead on routine operating decisions that are more accessible to precise description and quantitative analysis. 
For that reason much more theory exists on the Choice phase than on the Intelligence and Design phase.

Many other authors (Landry et al. [1985] and Sol [1987, p. 205]), too, have stressed that more attention should be paid to the first two phases of the decision-making process than is currently is being done. Much research effort is spent on the Choice phase, i.e. developing better algorithms for solving problems that are already well-structured. In practice, however, identifying, defining and structuring the problem is much more important. If Intelligence is not given the attention it needs, the wrong problem may be solved. There is a danger that a very good solution may be found to the wrong problem. It is much better to find an acceptable solution to the right problem. If Design is not given the attention it needs, a choice may be made from a set of alternatives, which is too limited. This may result in rejecting a very attractive alternative, because it is not even taken into consideration.

Exhibit 1-3 lists the main activities in the three phases of Simon's model. Three activities listed here as part of the Choice phase are usually considered to be part of the Design phase: the generation of statistics on alternatives, the simulation of results on alternatives and the explananation of the alternatives. Many authors argue that structuring the problem, which is a part of the Intelligence phase, is of crucial importance. 


\title{
Intelligence \\ -gather data \\ -validate data \\ -(dis)aggregate data \\ -identify objectives \\ -diagnose problem \\ -structure problem
}

\author{
Design \\ -gather data \\ -manipulate data \\ -quantify objectives \\ -generate reports \\ -generate alternatives \\ -assign risks or values to alternatives

\section{Choice} \\ -generate statistics on alternatives \\ -simulate results of alternatives \\ -explain alternatives \\ -choose among alternatives \\ -explain choice
}

Exhibit 1-3. Activities in the three phases of Simon's decisionmaking process model according to Sprague and Carlson [1982].

Structuring a problem means breaking down the problem into a number of subproblems that better fulfil the above-mentioned conditions for a well-structured problem, see Bosman [1986]. 
A clear example of structuring a problem is the corporate policy followed by the two founders of the multinational electronics corporation Philips. In order to make their company succeed (an ill-structured problem), one of the brothers, the production manager, aimed at producing more light bulbs than his brother, the sales manager, could sell, while the sales manager tried to sell more than his brother was able to produce. By breaking down their initial ill-structured problem, both of them ended up with a well-structured problem.

We define a decision strategy as a way to structure a problem. It is a breakdown of the initial problem into a number of subproblems that are better structured and therefore easier to handle. Usually, there are numerous ways to structure a problem, but not all of them are equally effective.

Following Keen and Scott Morton [1978] we define efficiency and effectiveness of decision-making as follows. Efficiency is performing a given task as well as possible in relation to some predefined performance criterion. Effectiveness involves identifying what should be done and ensuring that the chosen criterions are the relevant ones. At the higher levels in an organization effectiveness tends to be more important than efficiency, while at the lower echelons, efficiency is more important. People at the higher levels are the ones who determine what is important to the organization and what is not. They identify what tasks should be executed, and what the relevant performance criterions are. These higher level people delegate these tasks, and those at the lower level, who actually execute the task, try to perform that given task as well as possible in relation to the given performance criterion. 
When a decision-maker starts to work on an ill-structured problem he does not yet have a clear idea what performance criterions are relevant, and what alternative courses of action there are. While he works on solving the problem, the problem gradually becomes more structured to him. We regard the illstructuredness of a problem as a subjective phenomenon, i.e. a problem may be ill-structured to someone at one point in time and may be structured to him at some other (later) point in time. Likewise, a problem may be structured to one person and ill-structured to someone else. A problem is not structured or ill-structured per se: it all depends on the person and on the moment.

Effective decision-making involves structuring a problem, i.e. identifying what the problem really is, what alternatives there are and what the performance criterions are.

A conclusion from this review of the decision-making literature is that ways to structure the decision-making process promise to achieve more effective decisions. Decision strategies should lead to more effective decision-making. Decision strategies deserve more attention than they have received in the literature. 


\subsection{Decision Support Systems Literature}

We start this section by delineating decision support systems from other information systems. Next we describe the history of decision support systems. Third we analyze the components of a decision support system. Fourth, we describe the kind of support is given by decision support systems. Finally, we study of experiences in the decision support systems field and indicate some future developments.

\subsubsection{TAXONOMY OF INFORMATION SYSTEMS}

In order to make clear what distinguishes decision support systems from other information systems, we present a taxonomy of applications of information systems. This taxonomy categorizes information systems on the basis of their function into three types. These types are usually called: transaction processing systems, management information systems, and decision support systems. In many companies, these types of information systems appear in a certain historical order: first a transaction processing system is implemented, later a management information system and finally a decision support system. That is the reason why these three systems are often presented as stages on the information systems development path, and not as types of information systems.

\section{Transaction Processing Systems}

The function of transaction processing systems is gathering, updating, and presenting information according to predefined procedures. Before computers were used, transaction processing was done manually or mechanically on machines such as 
bookkeeping-machines. Computer-based data processing has altered the speed and complexity of transaction processing, but not the basic function.

The development method for these information systems is usually linear. Since transaction processing systems handle wellstructured processes, it is important that predefined procedures are precisely determined before the system is built. The information needs are fully specified; subsequently, the functional and technical designs are made, and the system is built. Because of the often immense volume of transactions to be processed, efficient programming is important.

Technologically, the construction of transaction processing systems is dominated by constraints, e.g. in processing speed and memory capacity. Transactions may be processed in batch mode, i.e. scheduled and optimized computer runs, or on-line.

The support of decision-making is very limited. Transaction processing systems affect only routine decisions.

The organizational level at which transaction processing systems are applied is the operational level. For the work of middle and top management the introduction of transaction processing does not have real impact.

Examples of transaction processing systems are a payroll system, and a sales order processing system. 


\section{Management Information Systems}

The function of management information systems is providing management with reports for decision-making purposes. These reports show data aggregated according to a predefined format. The information provided is well-defined. An implicit assumption here is that the inner workings of an organization can indeed be described by a set of coupled models of different levels of aggregation that together make up a total system.

There is not a big difference in development method of transaction processing systems and management information systems. The manager's information needs are fully investigated before system building starts. A later casual change of the system to adapt it to the manager's changing requirements is rare.

The technology used in management information systems is characterized by higher processing speeds and direct access memories. The reports produced by the system are either printed in batch or queried on demand. These query options, however, normally include only a set of predefined data extraction operators. A management information system is often built upon an existing transaction processing system. Hence, a management information system can be regarded as a stage on the information systems development path, coming after a transaction processing system.

Support of decision-making consists of the production of reports that usually present information on the current status of the company or developments of the recent past. These reports can either be routine periodic reports, or exception reports that highlight deviations from the standard. 
Management information systems are aimed at the operational and strategic organizational levels: middle and top management.

An example of a management information system is a general ledger system with managerial reports, such as a monthly profit and loss statement.

\section{Decision Support Systems}

The function of decision support systems is supporting management decision-making, especially in ill-structured problems, in order to improve its effectiveness.

The technology that has enabled the rise of decision support systems includes on-line accessible database systems, interactive programs, and data-communication.

The development method of decision support is basically different from transaction processing systems and management information systems. Since decision support systems are aimed at ill-structured problems, the information needs can not be exactly defined beforehand. Therefore, a linear design method, where the specifications of the system must be given in advance, is not appropriate for the design of decision support systems. An incremental design method is more suitable for the building of a decision support system. The building process is started with a small system, that fulfills only the very basic functions expected from the decision support system. Gradually, when more requirements arise during the use of the small initial system, the system is expanded. Because of the rise of high level programming languages, this approach of continual change of the system is viable. 
Decision support is needed at all levels in the organization. The decision-making which occurs at several organizational levels must be frequently co-ordinated. Therefore, an important capability of decision support systems is the communication and co-ordination between decision-makers across organizational levels, as well as at the same level, see Sprague [1980], Bosman [1986].

Examples of support of decision-making provided by decision support systems are:

- high level programming languages,

- simulation languages,

- database management,

- electronic mail,

- scheduling systems,

- financial modeling, and

- statistics.

After this description of decision support systems and the characteristics that distinguish them from other information systems, we turn our attention to the history of decision support systems.

\subsubsection{HISTORY OF DECISION SUPPORT SYSTEMS}

Sol [1987] has sketched a history of decision support systems. In the history of decision support systems, we can distinguish four phases. In the early seventies attention was directed towards the decision support system concept. In the late seventies the decision support systems movement originated. This movement developed into the decision support system bandwagon during the early eighties. In the latest phase there 
is a call for a major re-orientation of the decision support system efforts. We now describe these phases.

\section{Decision Support System Concept}

In the early seventies decision support systems were defined as computerized systems that support decision-making. The basis was the application of interactive programming techniques and databases to improve decision-making processes.

The concepts involved in decision support systems were first described by Gorry and Scott Morton [1971] in their classic article "Framework for Information Systems". Gorry and Scott Morton described a new class of information systems that was meant to be used directly by decision-makers and their staff. These systems incorporated both analytical capabilities and traditional data access and reporting capabilities to aid in decision-making. By the mid-1970's efforts to understand and to apply this new concept were underway, and reports of these efforts began to appear in the professional literature, see Elam et al. [1986].

The concept of decision support systems provided a focus for applied research in the use of computers for management. This research had existed since the forties, but was not yet labeled decision support. Systems that produced some information to support managers in making decisions have been around as soon as the first computer was built: during the Second World War a computer was used in solving problems on operations by the U.S. Armed Forces, see Miller and Star [1960, p. 103].

We call the early 1970's the era of the decision support system concept, because in this period the concept of decision support system was introduced. Decision support system was a new 
philosophy of how computers could be used to support managerial decision-making. This philosophy embodied unique, exciting ideas for the design and implementation of such systems.

There has been confusion and controversy over the interpretation of the notion decision support system. The origin of the notion is clear:

1. "Decision" emphasizes the primary focus on decision-making in a problem situation rather than the subordinate activities of simple information retrieval, processing or reporting.

2. "Support" clarifies the computer's role in aiding rather than replacing the decision-maker.

3. "System" highlights the integrated nature of the overal approach, suggesting the wider context of user, machine and decision environment.

In practice, however, this decision support system definition is much too broad to provide a meaningful categorization of available technology. Almost anything could qualify as a decision support system - from a sophisticated interactive decision-modeling system, through a programmable hand-held calculator to a cup of coffee.

There was a strong cognitive emphasis on individual decisionmakers.

\section{Decision Support System Movement}

The late seventies saw the decision support system movement, that emphasized interactive computer-based systems which help decision-makers utilize databases and models to solve illstructured problems. The emphasis shifted from decision-making processes to the support of personal computer use with aids 
to quickly develop applications. In 1978 Keen and Scott Morton wrote a book entitled "Decision Support Systems: An Organizational Perspective," which became a standard work of reference for several years. They introduced the definition of decision support systems as computer systems having an impact on decisions where computer and analytical aids can be of value, but where the manager's judgement is essential. They excluded from their definition those situations where the decision rules and operating procedures are already pre-defined or where the objectives and constraints have been pre-specified because in both cases the outcome is largely automatic and the need for post-output judgement is limited. They categorized the latter among the management information systems.

\section{Decision Support System Bandwagon}

The early eighties saw the decision support system bandwagon. All systems supposed to improve effectiveness of managers are labeled decision support system. Decision support system becomes a multi-billion dollar market and many vendors tried to grab a part of it.

The early eighties showed substantial advances in computing technology and applications, and these led to new ways and means of computer-assisted decision-making which were not available before. A great many software products which are labelled as decision support systems was coming on the market, see Freyenfeld [1984].

Disciplines that recognize the commercial attractiveness of the decision support system-label are operations research, management science, cognitive psychology, behavioral decision theory, information economics, computer science and political 
science. Phenomena like information center and prototyping are heavily associated with decision support systems.

In 1982 Sprague and Carlson wrote their book entitled "Building Effective DSS." This book is different from those written before on decision support system, since it focuses on how to develop a decision support system, while earlier books focused on describing decision support systems. Their book describes how the decision support system development differs from developing traditional computer-based systems and describes the steps and components necessary to develop effective decision support systems.

Sprague and Carlson [1982] identified three levels of software technology: specific decision support systems, decision support system generators and decision support tools. A specific decision support system is the application, that is tailormade for a specific decision-maker to deal with a specific set of related problems. A decision support system generator is a package of hardware and software that provides a set of capabilities to quickly and easily build a specific decision support system. Decision support tools are the elements which facilitate the development of a specific decision support system or a decision support system generator.

Sprague and Carlson view a decision support system generator as having three principal components: a data subsystem, a models subsystem and a user-system interface.

The data subsystem is the database containing three types of information. First there are the internal data that are produced by the transaction processing system of the organization. These are usually aggregated data: routine information per company, 
department or group of products, see Sol [1985]. Next there are the other internal data that are not registered on a routine basis, such as intermediate outcomes of decision-making processes that are still in process. Finally, there are data from external sources, such as market research data from companies provided on-line access to the research data they gathered.

In most decision support systems the data subsystem is a database separate from other operational databases within the organization. Recent advances in software and telecommunications technology have made it fairly easy to link the data subsystem of a decision support system with corporate transaction databases. For the decision support system-user this is a considerable advantage, since the aggregated data in the data subsystem might raise questions that can only be answered by investigating the disaggregated data.

The model subsystem is the part of the decision support system that manages models and analysis programs similar to the data subsystem manages data.

The user-system interface is the most important subsystem of the decision support system. The significant progress that decision support systems show over earlier systems is in power, flexibility and usability characteristics. Systems with strong computational algorithms or excellent data access routines have been around for years. Their effectiveness was limited, however, because they were difficult to use.

Several other authors have given their view on what components a decision support system consists of. Here we give the view of Bonczek et al. [1981]. Later in this section we 
shall give Sol [1987]'s integration and extension of Sprague and Carlson's and Bonczek's views.

Bonczek et al. [1981] view a decision support system as having three principal components: a language system, a knowledge system and a problem-processing system, see exhibit 1-4.

They define the language system as the total of all linguistic facilities made available to the decision-maker by a decision support system. The language system is the user-interface; it handles the communication between user and system.

The knowledge system is defined as a decision support system's body of knowledge about a problem domain. It typically includes large volumes of data on facts that the decision-maker has neither the time, the inclination, nor the opportunity to absorb into his own memory. In other words, the knowledge system consists of data files or data bases.

The third component in this view of decision support systems is the problem-processing system. The problem-processing system is defined as the system that takes problems and problem domain knowledge, and produces information that supports (enhances or enables) a decision-making process. These problems must be formulated according to the language system's syntax and the problem domain knowledge must be organized following the knowledge system's representation rules. 


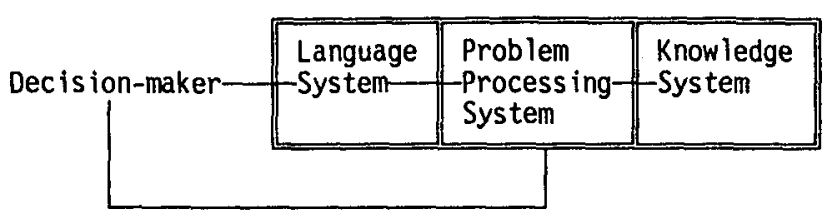

Exhibit 1-4. Bonczek et al. [1981]'s view of a decision support system.

\subsubsection{SUPPORT PER PHASE OF \\ THE DECISION-MAKING PROCESS}

The kind of support required from a decision support system differs over the phases of the decision making process. A specific decision support system supports one or more of these phases.

\section{Intelligence Phase}

The Intelligence phase involves the continual scanning of the environment for problems. The purpose of the Intelligence phase is acquiring knowledge of what is going on in the environment of the decision-maker, both inside and outside the company, like a watchdog.

As described in section 1.2, the activities in the Intelligence phase are twofold. On the one hand there is the gathering, validating and (dis)aggregating of data. On the other hand there is the identification of the objectives, and the diagnosis and structuring of the problem. First we analyze the handling of data and next the problem structuring part of the Intelligence activities. 
In the handling of data decision-makers can be supported by information systems that provide periodic reports and exception reports. These information systems might as well be labeled management information systems. In case these regular reports raise questions for the decision-maker, he should be able to conduct ad-hoc inquiries. He might like to go from the aggregate information as presented to him in the routine reports, to disaggregated data, to look for the causes of a deviation from the standard. The basic function of an information system here is providing data. The decision-maker's interface with the information system consists of regular reports and a query language.

The second group of activities in the Intelligence phase is the diagnosis and structuring of the problem and the identification of the objectives. The decision-maker usually begins with little understanding of the decision situation or the route to its solution; he has only a vague idea of what that solution might be and how it will be evaluated when it is developed, see Mintzberg et al. [1976, p. 250].

Decision-makers can be supported by splitting up complex problems into manageable steps. This can be done by experts in the field who suggest which part of the problem should be analyzed first.

\section{Design Phase}

As described in section 1.2, the activities in the Design phase of the decision-making process consist of the generation of alternative courses of action, quantifying the objectives, and assigning criteria values to the various alternatives, see Sprague and Carlson [1982]. 
Davis and Olson [1984] state that the following three iterative steps are typical when considering alternatives:

1. Support in understanding the problem. A model of the situation needs to be built, and the assumptions of the model should be tested.

2. Support for generating alternatives. By playing around with the model, ideas for solutions usually come up.

3. Support for testing feasibility of solutions. This analysis may be performed either by human judgment or by analyzing the proposed solutions using models.

\section{Choice Phase}

This phase consists of choosing an alternative. There are many methods for choosing alternatives. Optimization models are not typical for decision support systems. "What-if" analysis and sensitivity-analysis are very useful and very common in the Choice phase, see Kleijnen [1987, p. 136].

\subsubsection{FUTURE DEVELOPMENTS}

Elam et al. [1984] define a new vision for decision support system. They observe that decision support system currently built are passive. These systems respond to "what-if" questions but do not serve as advisers, devil's advocates, discussants or experts. Their vision requires more active tools that encourage a deeper unerstanding of problem situations. According to Elam et al. [1984], a major impediment to achieving this vision, is not the software, but the absence of new ways of defining 
models, of structuring problems, of handling multiple-criteria or open-ended tasks, of managing ambiguity and complexity, and of tackling new classes of decisions and new contexts of decision-making. They propose to confine the notion of decision support system to "the exploitation of intellectual and computer related technologies to improve creativity in decisions that really matter."

Elam et al. [1984, p. 22] come up with a number of research questions that they feel need more attention. One of these questions is how to study and measure effectiveness, quality of decision-making, learning and change. They argue that research into the impact of decision support systems on efficiency or effectiveness of an individual executing one or more tasks, has lacked both rigor and relevance. In our research we address the question of effectiveness of decision support system, using rigorous measurement techniques.

Weber [1986] responds to the paper by Elam et al. [1984]. She recommends problem decomposition tools as intrinsic components of a decision support system: "Too often we try to find a solution without first understanding the problem. An understanding of the problem as a whole not only helps drive the process of decomposition but it also helps the solver simplify and concentrate on those details which are apt to contribute to problem resolution. The next step is to break the problem down into its components. Successful problem solvers decompose complex problems into more manageable solutions. A single problem can be a complex of hundreds of subproblems, each of which can be resolved so as to produce a cluster of acceptable solutions. When the optimum solution of one subproblem entails the acceptance of a poor solution for another, the solver must rank order the complex of 
solutions. In such a situation, the task of reconciling solutions with one another can be difficult and time-consuming. A decomposition tool could help to manage the complex process by tracking and ordering subproblem solutions. It would, however, be the manager who would eventually need to select and implement a coherent solution structure."

Keen [1987] advocates "an explicit effort to influence and guide decision making, while respecting the primacy of judgement and focusing very carefully indeed on how managers think, what aspects of their decision-making process they are likely to be willing to delegate, their expectations and attitudes about the use of analytic tools, etc." The aim of our research is to analyze this decision making process. Especially, Keen recommends using the decision support system builder's understanding of the decision domain to help point to and even select alternatives, rather than just evaluate the decision maker's set of choices. In other words, Keen advocates a shift in attention from the Choice phase towards the Design phase of the decision making process.

To explain what kind of support information workers need from decision support systems Sprague [1986] and Sprague and McNurlin [1986] make a distinction between type $I$ and type II work. It is a dichotomy that focuses on job procedures and goals, rather than on the type of data (for example, numbers versus text) or the business function (production versus accounting).

Doing type I work means following predefined procedures, while type II work is only determined by its outcome. A type I task can be assigned to an information worker by explaining the sequence of steps required to accomplish it. With a type 
II task, the desired outcome must be specified. Figuring out the necessary steps in the sequence is part of type II work. Delegation of type I work means specifying how to do it, while delegation of type II work only means specifying what to do. Performance of type I work can easily be measured by how quickly or efficiently or how many times a certain procedure or process is executed. Performance of type II work can only be measured by how well a certain goal is reached.

Both solving ill-structured and well-structured problems is type II work. Type I work usually involves a huge number of transactions that are all of relatively limited value or cost, type II work consists of a small number of transactions with high value or cost. As a corollary, type I work uses data in a format, while type II work deals primarily with concepts which are referred to as soft data, see Brookes [1988]. Exhibit 1-5 summarizes the different characteristics of type I and type II work.

A major benefit of this dichotomy of information work is that it reveals how much of the efforts in transaction processing systems and management information systems have been devoted to supporting type I work. According to Sprague, type I work is the 'wave of the past', while the wave of the future is to apply the rapidly expanding information technology to support type II work.

In our research we aim to test the effectiveness of different ways to support type II activities. Our focus is on the essence of the difference between type I and type II work: as noted above, the crux of type II work is identifying the sequence of steps, necessary to achieve the desired outcome. We give decision-makers a helping hand in structuring the decision- 


\section{Sec. 1.3 DECISION SUPPORT SYSTEMS LITERATURE}

making process. We do not give them standard procedures they can follow.

Type I work

Type II work

Well-structured procedures

I11-structured procedures

Output measures defined

Output measures less defined

Focus on procedures

Focus on problems and goals

Focus on efficiency

Focus on effectiveness

Handling of data

Handling of concepts

Predominant ly clerical work

Managers and professionals

Examples:

Examples:

- back office

- mortgage servicing

- loan department

- asset/liability management

- payroll processing

- planning department

- check-processing

- corporate banking

Exhibit 1-5. Type I and type II work according to Sprague [1986]. 


\subsubsection{EXPERIENCES}

A way to prepare for the future is the analysis of past experiences. Decision support systems have been around for more than a decade now, and numerous interesting experiences have been gathered on their use. A number of dilemmas that have surfaced are detected by Sol [1987]. The ones that are the most relevant to our research will be analyzed here.

The first dilemma is the dilemma of knowing and making. Decision support systems are supposed to be aimed at solving ill-structured problems. It is surprising, however, how little attention is paid to the first steps of the decision-making process. In section 1.2 we introduced the following four phases in the decision-making process: conceptualization, problem specification, solution finding and implementation. Before a decision-maker is able to find a solution and implement it, he has to know the problem situation thoroughly, i.e. knowing should precede making. Look before you leap.

So, here is a dilemma: everybody says that decision support systems should support problem solving in ill-structured problem situations, yet decision support systems do support mainly the latter two phases of the decision-making process, and not the problem structuring part of the Intelligence phase. The decision support system movement pays lip service to decision support systems solving ill-structured problems.

The dilemma of incremental design is closely related to the first dilemma. Incremental design aims at quickly creating a working prototype. Using this prototype, the functional needs for a system in the given problem situation can be uncovered. Next, the functions of the prototype can be expanded gradually. As 
a design method, incremental design or prototyping is the antipode of the linear method. In the linear design method, the design process is split up into a number of phases, each of which has its own deliverables, budget, manpower, documents and authorization. Prototyping can serve several purposes:

- getting a better insight into the problem situation,

- specifying the exact information needs,

- developing the user interfaces.

Experiences with prototyping as a design method indicate:

- Instead of using the prototype to explore the problem situation, decision-makers tend to concentrate on quickly coming up with a working system and use it to find a solution for their problem.

- The solution is readily accepted within the organization, which ends further experimenting with the prototype.

An intrinsic feature of the incremental design process of decision support systems is that building a system almost immediately starts when the problem is detected. "Shoot first, ask questions later." Gradually, by developing the initial small system (prototype) the decision-maker learns more about the problem situation. So here is a dilemma: before starting to build, the decision-maker should know the problem situation, but the way to get to know the problem situation is to build a decision support system for it. This process of building and problem solving does not always converge to a solution.

Two other dilemmas touch on the subject of co-ordination of personal computer use. Typical for decision support systems in organizations is their use by users for personal computing. This does not necessarily mean that a decision support system is implemented on a personal computer, but it means that the 
decision-maker uses the system individually, completely according to his own wishes, see Sol and Verrijn Stuart [1988]. This can easily lead to a chaos of software, hardware, personal data bases and models. An information plan is necessary to prevent this from happening.

This dilemma has also been analyzed by Bosman [1986]. He proposes to create a network of specific decision support systems and he criticizes the currently available decision support system generators for their lack of adequate facilities to interconnect models.

Because of the cognitive constraints of the decision-maker, discussed in section 1.2, he often cannot recognize a problem at once, and if he can, he is unable to structure it without the assistance of instruments. In order to solve a problem, a decision-maker may divide a problem into parts and try to solve these subproblems separately. Although the breaking down of a problem to find solutions is rather common, the approach has intrinsic risks:

- Implicitly, the assumption is made that when the subproblems have been solved, the whole problem has been solved. This often leads to sub-optimal solutions: alternatives which are optimal within the boundaries of the subproblems, are not optimal for the whole problem. The subproblems are interdependent, see Kleijnen [1980, p. 102].

- Personal computing tends to aggravate the co-ordination problem instead of solving it.

These dilemmas necessitate the rethinking of the decision support system concept. A clearer delineation of the decision support system concept is needed in order to make decision support system foster effectiveness and efficiency of 
organizational decision-making. Sol [1987] takes up the process of problem solving in a knowledge-based framework, which may give a solution to the dilemmas formulated. Sol thus proposes an integration of the views of Sprague [1980] and Bonczek et al. [1981], as given in exhibit 1-4. In exhibit 1-6 the extension of the two frameworks into a new one is given.

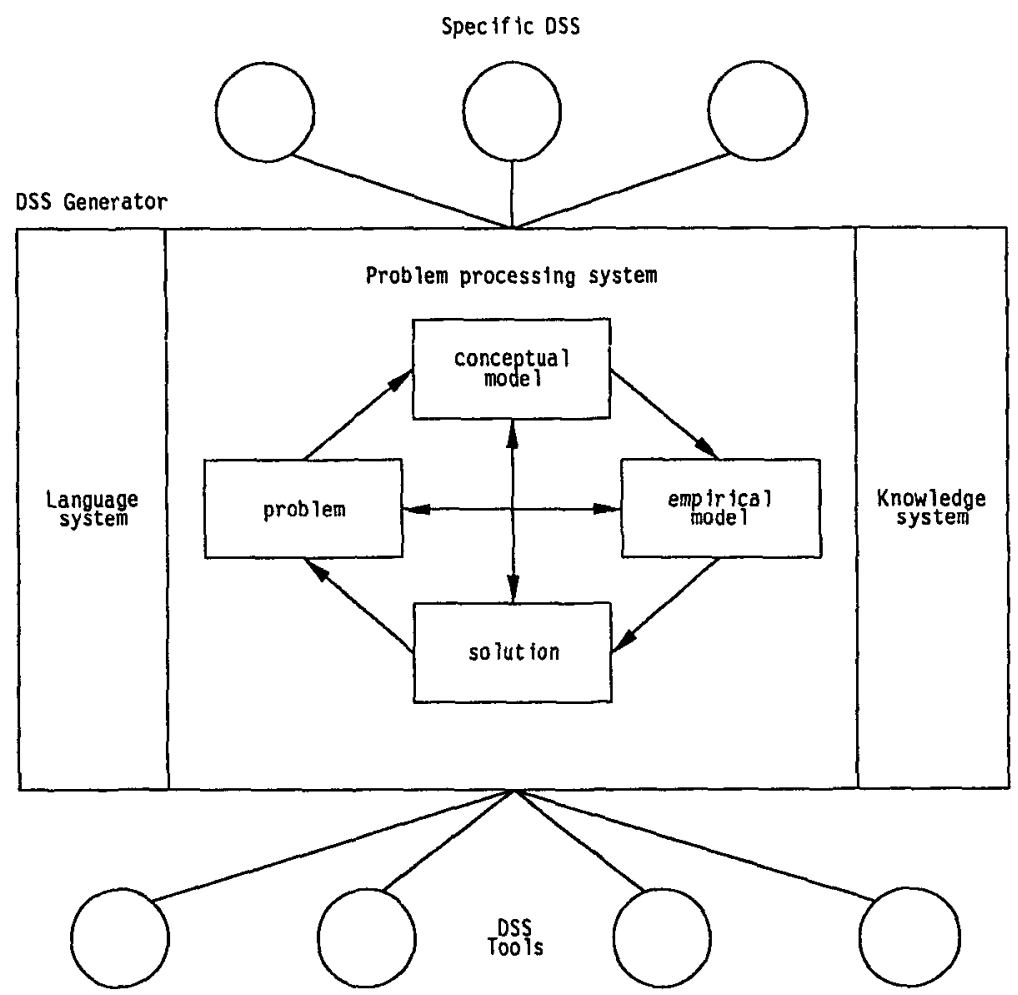

Exhibit 1-6. Sol [1987]'s view on Decision Support Environments. 
Sol proposes to direct decision support system research to the concept of decision support system generators or, more generally, decision support environments. One of the reasons for this choice is the limited generalizability in dealing with specific decision support systems. Another reason is that all stages in the process of problem solving have to be addressed, not only at the empirical, problem-dependent level, but also at the conceptual level.

Our research question and hypotheses fit within this research into decision support environments. 
GAMING

\subsection{Gaming Literature}

\subsubsection{RESEARCH APPROACHES}

There are several types of empirical research on decision support systems. Following Van Horn [1973] we distinguish four approaches:

\section{Case study}

Investigation of a single organization with respect to a number of variables. Case studies do not provide experimental design or control; the observer simply records what exists. This approach is followed by Thierauf [1982].

\section{Field study}

Investigation of several organizations with respect to one or more variables with an experimental design but without experimental control. Examples are Koeleman [1988] and Molengraaf [1988], who interviewed users of decision support systems at eight companies working with one brand of decision support system generator and eight companies working with another brand of decision support system generator; these authors compared the findings. Some other examples are Sanders and Courtney [1985] and McLeod and Jones [1986]. 


\section{Field test}

Investigation of one or more organizations with respect to one or more variables with a specific experimental design and with experimental control. Sprague [1971] describes one of the few examples of this approach.

\section{Laboratory study}

Investigation of aspects of information systems within a simulated environment. A substantial body of research following this approach is described by Dickson et al. [1977].

After an in-depth analysis of many empirical research projects following these four methods, Van Horn draws the following conclusions.

Case studies provide very little insight into the key research issues of information systems. This conclusion is partially attributed to the complexity of the research problems, and to the lack of careful chronology and detail. McLean [1973] adds one more frequently leveled criticism to case studies: How do we know whether the research outcomes extend beyond the single organization studied?

Field studies, attempts by researchers to gather data in ongoing uncontrolled situations, are inefficient due primarily to the large amounts of data that have to be collected. Another major problem cited is the lack of experimental control to isolate the key independent variables.

Field tests, attempts to introduce change and measure some aspect of the system, are plagued by the subordinate role a controlled study is forced to play to the necessary operations 
and survival of the organization. Field tests described in the literature are extremely rare and the ones that are published are sad stories, according to Van Horn. McLean [1973] adds that the competing demands of careful experimental control and the pressing concerns of the organization inevitably yield to the latter and so almost all field tests end up becoming case studies or field studies.

Laboratory studies, attempts to control and measure phenomena through the creation of a model of the system, offer the only viable approach for many aspects of research into management information systems.

We further distinguish between three types of laboratory experiments. Two of these three types are special kinds of simulation. In the third type of laboratory study, the participants are confronted with a case-description. We call this the case-study/textbook problem approach.

Following Shannon $[1975$, p. 2] we define simulation as: "the process of designing a model of a concrete system and conducting experiments with this model in order to understand the behavior of a concrete system and/or to evaluate various strategies for the operation of the system."

Simulation studies are either pure-machine simulation studies or gaming studies. In pure-machine (computer) simulation all variables are determined by a computer program, see Kleijnen [1980] for a survey of simulation of information systems. Gaming is simulation, in which one or more input variables (decision variables) are determined by human actors. The players receive feed-back of intermediate results, and are able to adapt their behavior accordingly. So, we define gaming 
as a special kind of simulation. Well-known gaming examples are war games and management games, also referred to as business games. Management games simulate the management of an organization, usually a company. Total enterprise business games simulate the management of a whole company, see Keys [1987]. Functional games simulate one business function in particular, for example marketing, production or finance, see Biggs [1987], Gold and Pray [1984], Partridge et al. [1984] and Radosinski [1985].

In the case study/textbook problem approach the real system is represented by a written description only. No decisions can be made influencing the real system, so no results of the implementation of the decision can be measured. This approach is static.

For research into information systems, we strongly prefer gaming over the case study/textbook problem approach for the following reasons. First of all, the situation is much more realistic, because it is dynamic. Second, the data. become available to the decision-makers step by step, which is more realistic than a situation where all information is given at the beginning of the problem-solving process. Finally, the decisionmakers can use feed-back information for corrective action, which can be extremely useful, see Partridge et al. [1984].

Still many experiments following the case study/textbook problem approach are conducted. See Benbasat and Dexter [1985], DeSanctis and Dickson [1985], Benbasat and Dexter [1986], Dickson et al. [1986], Remus and Kottemann [1987], Umanath and Scamell [1988]. 
Gaming should not be confused with game theory. Game theory is concerned with the mathematical analysis of decisionmaking and concentrates on concepts like utility functions, and payoff matrices. Game theory does not pay much attention to the Intelligence phase of the decision-making process, and its merits are primarily confined to searching for an optimal alternative in well-structured problem situations. The seminal work in the field of game theory is Von Neumann and Morgenstern [1953], see Kleijnen [1980, p. 125].

\subsubsection{ADVANTAGES AND DISADVANTAGES OF LABORATORY STUDIES}

The advantages of a laboratory approach over other research approaches concern the measurement and control of variables. The experimenter can manipulate the nature of the real system and the nature of the information system used by the decisionmaker to determine how changes influence decision-making. The laboratory situation allows the researcher to control variables that may otherwise confound results.

We are talking here about the so-called internal validity of the experiment. Cook and Campbell [1979] define internal validity as "the validity with which we infer that a relationship between two variables is causal or that the absence of a relationship implies the absence of cause". Internal validity deals with the proper application of experimental treatments. If the experimenter has not carefully ensured that the outcomes being observed are truly a function of experimental manipulation of the independent variables, internal validity of that experiment is questionable. In other words, if internal validity is lacking, no statements about cause and effect can be made. It is easier 
to achieve internal validity in a laboratory experiment than in other types of empirical research, since the experimenter has much tighter control over the experiment. Another type of validity, the external validity, will be discussed later in this section.

Another advantage of laboratory studies is the fact that some outcome variables may be unavailable in field settings, but can be objectively measured in a laboratory setting. It is far easier to gather data, since the whole experiment takes place within the boundaries of the laboratory.

The final advantage of a laboratory approach is that processes develop much quicker in a laboratory-setting than in a realworld setting, which diminishes the time needed to do one observation. Because less time is spent on gathering a single observation, it is possible to do more observations in a laboratory than in real life within the same time frame and with the same budget. Often this makes up the difference between statistical analysis techniques being applicable or not. Data gathered from a field test are only seldom statistically analyzed.

Among the disadvantages of laboratory studies, external validity is the most widely mentioned. Research findings based on laboratory studies may not be generalizable to real-world settings if the laboratory setting markedly differs from the realworld setting it is meant to simulate, see Courtney et al. [1983]. The effects of this disadvantage may be mitigated by the participation of subjects that are typical of real-world decision support system users, see Argyris [1980]. 
The pivotal question is: How realistic is gaming in decision support system research? There are two aspects of gaming that are relevant here.

First of all there is the so-called validation of the model. Validation of the simulation model is the investigation of the correspondence of the model with the real-life situation, see Sol [1982]. In other words: Is the game a realistic representation of the real system? We can perform this correspondence test by comparing the outcomes that result from certain decisions in the game, with the outcomes that the same decisions have led to in practice. This is the validation that is an essential part of any simulation study, both gaming and pure-machine simulation, see Sol [1982] and Stanislaw [1986]. However, a high degree of correspondence between model and reality leads to a high degree of complexity and a highly complex game is difficult to learn, play and lead. If a game is very complex, the treatments do not easily make a significant difference because many other factors are also influential. In a very complex game it is hard to identify any causal relationships, because there are so many factors which confound the results. These causal relationships are exactly what we are looking for when we apply gaming as a research approach. So here we have a dilemma: finding a trade-off between correspondence of model and reality versus simplicity of the game. Summing up their experiences from a number of experiments with a highly complex management game at New York University, Lucas and Nielsen [1980] state: "If an error has to be made in designing a simulation exercise for laboratory experiments, it should be made on the side of simplicity." 
Another aspect of gaming also determines how realistic the research results are: plausibility. Plausibility is the degree to which the players feel that the model resembles reality. It is the degree of correspondence of model and reality as perceived by the players. Plausibility is very important in gaming, since it has a crucial influence on the motivation of the players. It thus determines whether the players are apt to act in the same way as they would do in practice. Plausibility is also referred to as verisimilitude or face validity by some authors, see Norris [1986].

Validity and plausibility are not necessarily conflicting goals. The most obvious way to achieve plausibility is by building a valid model. As we saw before, a valid model often is a complex model. Meier et al. [1969] state that plausibility can also be achieved with a simple model, if only the model is well-designed. If a simple model is perceived by the players as being realistic and they feel that it reacts in a realistic manner to their decisions, plausibility is achieved. When doing research with the gaming approach, one aims to create an illusion for the players; so plausibility may be relatively more important than validation. In fact, realism is not really an issue because the primary duty of the game player is to strive to understand the environment in which he finds himself and to operate as effectively as possible within that environment, see Schellenberger et al. [1982]. Management games with a high degree of validity, i.e. correspondence with an actually existing real-life situation, are rare. A notable exception is reported by Bots, Van Schaik and Sol [1988].

Wolfe and Roberts [1986] define external validity of a management game in a slightly different way. They compare how well participants are performing in a management game 
and how well their business careers are developing in the first five years after playing the management game. For a number of career success measures a correlation was found; however, for some other measures there was no significant correlation.

Another drawback of laboratory studies, especially gaming studies, is the considerable cost involved. The development, use and maintenance of a game require considerable amounts of time and money. However, it is not clear whether laboratory studies are necessarily more expensive than real-world experiments, since real-world experiments can be expensive as well.

\subsubsection{A SYSTEM THEORETIC BASIS}

In this section the gaming approach to research into decision support systems will be given a system theoretic basis. As a starting point we take the information systems paradigm as defined by Brussaard and Tas [1980]. The information system paradigm is a way to describe an organization: "Every group of interdependent dynamic phenomena (every system) can be described as a real system (RS) and an information system (IS) with the information system controlling the real system."

The real system is that part of the real world that we want to control or investigate. For both control and investigation the real system has to be described. These descriptions or images of the real system are produced by the information system. So information systems contain and produce inages of real systems, but information systems themselves are also real systems and every (real) information system is a part of a 
larger (real) system on a higher level. The real system to be controlled may also be an information system.

The information system consists not only of the computer, the paperwork and the procedures (the 'formalized' information system), but also of the people that make decisions. For example, a warehouse can be thought of as the real system and the ordering department as the information system. Likewise, a manufacturing facility can be pictured as the real system and its planning department as the information system.

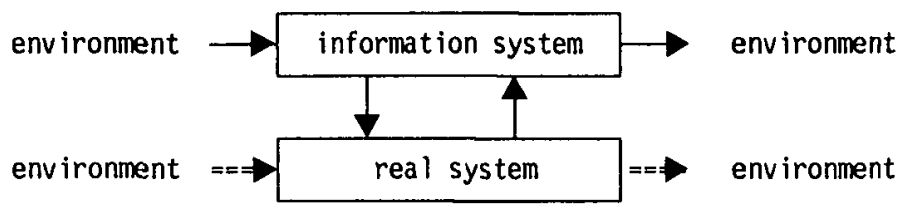

refers to: information (of all kinds)
$=====$ refers to: materials, services, money, energy

\section{Exhibit 2-1. The information systems paradigm.}

Exhibit 2-1 presents a diagram of the information systems paradigm. Processes in the real system are controlled by the information system. The information system receives information from the real system (for example observations) and sends information to the real system (for example decisions). Also, the information system receives information from the environment (like goals) and sends information to the environment (for example reports). So, both the real system and the information system are open dynamic systems. The environment sends messages to the information system, but not to the real system, since, according to Bots and Sol [1987, p. 
225], "this would imply that the information system does not really control the real system."

The information systems paradigm is recursive, i.e. the paradigm also holds for subsystems, for example, it holds for all real systems and information systems within the system (organization) considered. We call this the recursion principle.

Exhibit 2-2 presents the laboratory approach to decision support systems research, as seen from the information systems paradigm perspective.

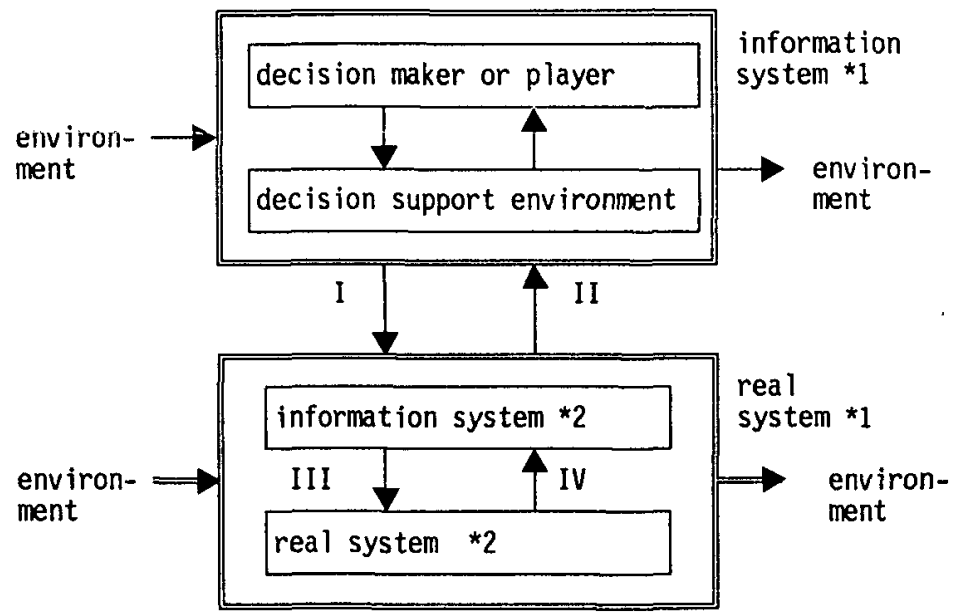

refers to: information (of all kinds)
refers to: materials, services, money, energy

Exhibit 2-2. The information systems paradigm applied to laboratory studies. 
A management game can be pictured as real system ${ }^{*} 1$. It can in turn be thought of as consisting of an information system and a reai system.

For example, the real system $* 2$ in this study is a simulated manufacturing company. Raw materials are input to this system and chemical products are output. In the laboratory setting this company is represented by a simulation model.

The information system ${ }^{*} 2$ is the transaction processing system and management information system that produces the regular reports. These reports reflect the state of the simulated company ${ }^{*} 2$. It also includes the clerks that are responsible for the processing. In the laboratory setting this information system is represented by a simulation model, as well.

The information system ${ }^{*} 1$ controls the real system ${ }^{*} 1$. This information system ${ }^{*} 1$ consists of the decision-maker, the player in the game and maybe a decision support environment, if he uses one. The decision support environment consists of the elements shown in exhibit 1-6.

The decision forms that go from the decision-maker to the simulated company are marked I. The forms that report how the company is doing, such as balance sheet and profit and loss statement, are marked II.

The decisions marked I, i.e. the plans, are processed by the information system ${ }^{*} 2$. It performs the detailed planning, such as which production-belt will produce which order, and sends commands (marked III in the exhibit) to the real system *2. For instance, aggregate planning is the task of the player; lowlevel scheduling is performed by information system ${ }^{*} 2$, see Sol [1985]. 
Sometimes unforeseen events may happen in the real system ${ }^{*} 1$ that thwart the execution of the plan, such as raw material shortages. To inform the information system ${ }^{*} 2$ of such discrepancies between plan and realization, real system *2 sends information (marked IV in the exhibit) to the information system $* 2$.

From exhibit 2-2 it becomes clear that the information system paradigm is recursive: the paradigm is applicable at two or more levels.

The information systems paradigm sheds new light on the relationship between action and behavior, as given in exhibit 1-1. Action (1) refers to the information system in exhibit $2-2$ and behavior (1) refers to the decisions marked I that go from the information system to the real system in exhibit 2-2. Action (2) refers to the real system and behavior (2) to the reports that go from the real system to the information system.

\subsubsection{OVERVIEW OF LABORATORY EXPERIMENTS}

Kleijnen [1980, p. 143-146 and p. 150-151] gives a comprehensive overview of laboratory experiments, aimed at various aspects of computer support for knowledge workers. Leitheiser [1986] gives an overview of more recently performed experiments. The list of opportunities for new experimental research relevant to knowledge worker support, has a prominent place for the examination of the effectiveness of decision support systems. He criticizes decision support researchers for the emphasis they put on the evaluation of features of decision support system generators to the total exclusion of evaluation of whole systems. Concluding from the 
many experimental studies that he examined, he states that efforts at modeling were promising but not carried far enough. He categorizes all decision support system-laboratory research into three groups, depending on whether they are aimed at either system variables, task variables or user variables. Leitheiser notes a neglect of task variables:

"In spite of the opportunity, only two studies manipulated the task and they looked at only one variable apiece. None of the studies attempted to associate the effects of system design features with task factors - an obvious research question."

As our research question and hypotheses will clarify, we shall look into this research question.

Next we consider a number of gaming experiments aimed at effectiveness of decision support systems.

One group of gaming experiments studies the effect of cognitive style. Examples are Lusk and Kersnick [1979], Benbasat and Dexter [1982], and Motiwalla and Pheng [1982]. This research topic is on the brink of extinction since the influential article by Huber [1983]: "Cognitive Style in DSS-Design: Much Ado About Nothing?" was published. He clearly concludes that cognitive style is not a solid basis for the design of decision support systems.

In another group of gaming experiments, effects of quality of information presentation is analyzed. This group of experiments is surprisingly large. In particular the comparison of graphical and tabular information presentation is a very popular research topic, see Benbasat et al. [1981], Benbasat and Dexter [1985], Benbasat and Dexter [1986], Benbasat et al. [1986], DeSanctis 
and Dickson [1985], Dickson et al. [1986], Hoadley [1986], Loy et al. [1987], Lucas and Nielsen [1980], Remus [1984] and Umanath and Scamell [1988].

A third group of laboratory studies investigates the effects of information overload on decision quality. Examples are Benbasat and Schroeder [1977], Chervany and Dickson [1974], Volonino et al. [1987].

A fourth group of laboratory research studies the support of the problem structuring activity in the Intelligence phase of the decision-making process (see section 1.2) by Shane et al. [1986], Pracht and Courtney [1986] and Dos Santos and Bariff [1988].

Shane et al. [1986] developed a decision support system that guides, instructs and provides reasoning in order to help the decision-maker identify strategic opportunities, problems and crises. They conducted an empirical study to examine the effects of this decision support system on performance in the problem finding or initial stage of the decision-making process. The results of the study indicate that using a decision support system can improve the decision-maker's ability to identify and assess problems in ill-structured problem situations.

Pracht and Courtney [1986] present a system that is based on interactive graphics software for structuring, representing and maintaining mental model knowledge in a decision support system environment. The system implements techniques of structural modeling. Structural models are directed graphs or diagrams which portray the user's visual image of the problem situation. Nodes represent variables and arcs represent causeeffect relationships among variables. The system supports 
structuring, capturing, storing and maintaining the knowledge contained in mental models. The results from a laboratory study with the system lend some credence to the contention that problem structuring systems may lead to better decisions, at least for some people.

Dos Santos and Bariff [1988] study how aids in model manipulation help in identification of a problem. One of their independent variables is the model manipulation strategy, which has two levels, namely user versus system-guided model manipulation. Subjects in the system-guided model manipulation treatment group were required to use the model by varying decision variables in a strict order imposed on them by the decision support system. If the subjects in this group did not follow these rules (which were explained to them by the decision support system), the decision support system provided guidance. The decision support system did not permit them to violate the order. Subjects who were not guided by the decision support system in their use of the model could vary decision variables in any sequence they chose. One of Dos Santos and Bariffs hypotheses was: Users receiving system guidance for the manipulation of model variables will be better at finding problems than users not receiving guidance. This hypothesis was supported by the experimental data. Systemguided model manipulation users performed better on the problem finding. Thus, the study showed that structured model manipulation does improve a user's performance. So system designers should provide aids that guide users in structuring their use of a model, in order to facilitate structured model manipulation, while not constraining creativity. 


\subsubsection{HISTORY OF MANAGEMENT GAMES}

War games are in many respects direct ancestors of today's management games. The surge in popularity of management games has been made possible by developments in operations research and information technology. One of the earliest war games was introduced at Schleswig in 1798, 'das Neue Kriegspiel,' see Cohen and Rhenman [1961]. It was the first war game in which actual maps were used, instead of game boards. During the nineteenth century, two styles of war games developed: the rigid type and the free type, corresponding to the opposing demands of realistic and playable games. Formal rules designed to reflect actual war as closely as possible characterized the rigid variety. Random effects were introduced by the use of dice. Extensive charts, tables and calculations were used to incorporate the exact details of troop movements, etc. In the free variety of war games the experienced judgment of human referees played a major role. As a result of their popularity in Prussia, war games quickly spread into other countries during the latter part of the nineteenth century. War games were introduced into the British Army in 1872 and shortly afterwards in the United States, notably at West Point. The greater ease of administration of the free war game made it more widespread than the rigid war game. Germany and Japan were the nations that made the most extensive use of war games during this century. The first widely known management game was developed after an exploratory visit by the American Management Association to the U.S. Naval War College in 1956. 


\subsubsection{RECENT TRENDS IN MANAGEMENT GAMING}

Recent developments in hardware and software technology have caused some exciting trends in gaming recently. First there is a trend from general to specific management games, i.e. from designing games with the intent to imitate a group of similar companies to designing games with the intent to imitate one specific company much more closely. Until recently management games used to be designed with the idea of a whole group of companies in mind. No management games were built as a replica of one particular company.

If a management game is typical for a whole industry (for example, the chemical industry) a manager from one chemical company will, at least vaguely, recognize some of the characteristics of his own company in the game. Some of the other characteristics of his company, however, will be missing conspicuously which makes him feel that the outcomes of the experiment may not be readily applicable to his own company. Because of the increased flexibility of software-technology, it has become much easier to adapt a game to the specific characteristics of a single company, with its own idiosyncracies.

Similar to this development is the so-called parametrization of games. The game-administrator can change the programparameters in order to adapt the game to the participants. Games can be designed so that they may simulate different realities according to the background of the participants: for example, if a group of production managers plays the game, the administrator can make the production planning decisions especially complex and interesting for this particular group. 
Another recent development in management games is the simplification of operating procedures made possible by the ubiquitous personal computer. A leader of a management game used to be plagued by a number of practical nuisances. For example, every round of play the decisions supplied by the players on paper, had to be fed into the computer manually, which is an error prone procedure. If all players have a personal computer available, decisions can now be entered by the players themselves on their own personal computers and be submitted to the game program via floppy or network. In terms of exhibit 2-2, information marked I and II is exchanged via floppy instead of paper. Advancing the game to the next period has thus become a matter of seconds. Also after every round of play the output of the game program had to be printed, which is a time-consuming chore. If all players have a personal computer with a printer connected to it, they can either view the results on screen or make hard copies themselves.

Finally, because the game program can be implemented itself on a personal computer, portability of the program has increased tremendously.

All these advancements will make gaming an increasingly popular teaching and research vehicle in the near future. 


\subsection{Problem Statement}

This study deals with the question of how decision-making in organizations can be supported in order to obtain better decisions. As suggested by the literature described in chapter 1 , we investigate both the effectiveness of a decision support system and a decision strategy.

A number of empirical studies into the effectiveness of decision support systems have been described in the literature. Some of these studies found that decision-makers using a decision support system or a decision support tool get better results than those doing without, see Benbasat and Schroeder [1977, p. 43]. However, an overwhelming majority of researchers did not find statistically significant differences in performance of users and non-users of decision support systems, see Joyner and Tunstall [1970], Lucas and Nielsen [1980], Cats-Baril [1982] and Goslar et al. [1986]. Furthermore, our earlier research has suggested that the use of decision support systems does not lead to an improvement in decision quality, see Van Schaik [1984], Van Schaik [1986], and Van Schaik and Sol [1986]. So, the research question here is: Does a decision support system increase decision quality?

The literature described in chapter 2.1 suggests that structuring a decision-making process may lead to improved decisions. This leads us to investigate whether decisions become better when they follow a well laid-out decision strategy. We compare the performance of decision-makers following a strategy which is regarded by an expert to be optimal, with the performance of decision-makers without such a strategy. Decision-makers working along the lines of this strategy might be doing better 
than decision-makers working in a less structured way. So, the research question here is: Does a decision strategy increase decision quality?

Next we describe in detail the hypotheses that are tested. These hypotheses concern both the use of a decision support system and the use of a decision strategy. All hypotheses are stated in the null-form, as is classical in statistics.

The first hypothesis concerns the experimental variable decision support system:

\section{Hypothesis 1}

Decision-makers using a decision support system show a performance that does not exceed that of decision-makers working without a decision support system. (Both types of decision-makers include those using a prescribed decision strategy, as well as those not using a prescribed decision strategy.)

The second hypothesis concerns the experimental variable decision strategy: we compare the performance of decisionmakers exposed to a prescribed decision strategy with the performance of decision-makers doing without the strategy designed by the expert.

\section{Hypothesis 2}

Decision-makers exposed to a prescribed decision strategy designed by an expert show a performance that does not exceed that of decision-makers without such exposure. (Both types of decision-makers include those using a decision support system as well as those not using a decision support system.) 
Results on the first hypothesis might be different for the decision-makers following a prescribed decision strategy and for those lacking a prescribed decision strategy. Therefore we state hypotheses 3 and 4 .

\section{Hypothesis 3}

Consider only decision makers not using a prescribed decision strategy. Decision-makers using a decision support system show a performance that does not exceed that of decision-makers working without a decision support system.

\section{Hypothesis 4}

Consider only decision makers using a prescribed decision strategy. Decision-makers using a decision support system show a performance that does not exceed that of decisionmakers working without a decision support system.

Similarly, results on the second hypothesis might be different for the decision-makers using a decision support system and those working without a decision support system. Therefore we state the hypotheses 5 and 6.

\section{Hypothesis 5}

Consider only decision makers not using a decision support system. Decision-makers exposed to a prescribed decision strategy designed by an expert show a performance that does not exceed that of decision-makers lacking a prescribed strategy. 


\section{Hypothesis 6}

Consider only decision makers using a decision support system. Decision-makers exposed to a prescribed decision strategy designed by an expert show a performance that does not exceed that of decision-makers lacking a prescribed strategy.

\section{Hypotheses 7 through 12}

These hypotheses are similar to hypotheses 1 through 6 . The difference is that profit is the dependent variable, instead of the composite performance score which will be described in section 3.7 .

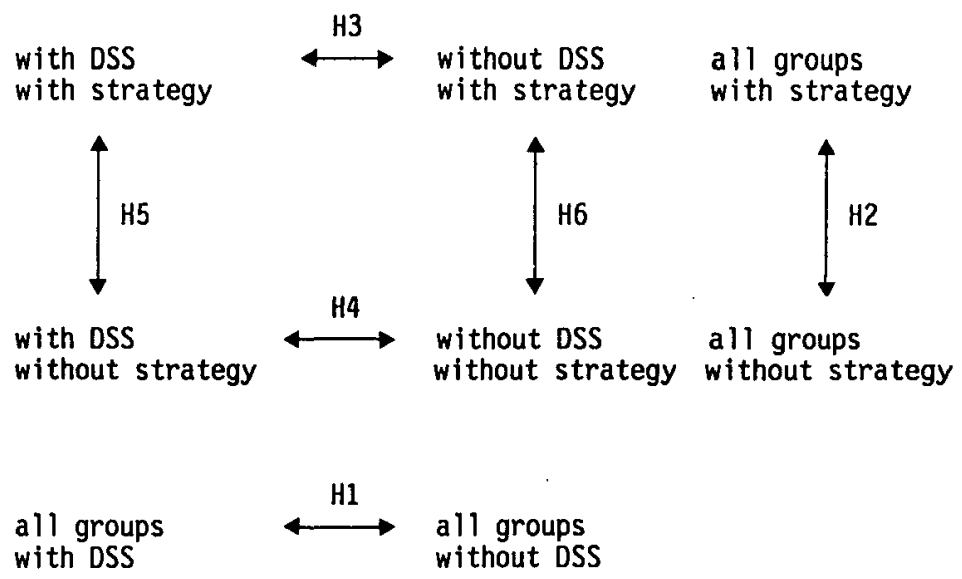

Exhibit 2-3. Research hypotheses. 
As a summary, exhibit 2-3 shows the research hypotheses. Hypotheses 1 and 2 concern the comparisons encompassing all subjects. Hypotheses 3 and 4 are the comparisons conditional on strategy. Hypotheses 5 and 6 are the comparisons conditional on decision support system. 


\section{APPROACH}

\subsection{A Game}

After an extensive search of available management games, we chose the VUMAS management game, see Van Schaik [1986]. VUMAS is described in detail in VUMAS Users Manual [1987]. Therefore, we give only a concise description of the game in this section.

The VUMAS management game was selected for this study because:

- it is complex enough to make the subjects feel as if they are in a semi-structured environment.

- it provides a realistic environment; VUMAS's extensive use suggests that the game is not too unrealistic a model, and in this sense the game has been 'validated.' See Kleijnen [1980, p. 157].

- VUMAS is widely used and readily available, thus providing other researchers an easily accessible means of replicating and extending this study. Courtney et al. [1983] advocate the use of a common gaming simulator. They state that gaming studies have contributed the most to management information systems literature, where there has been a continuity in gaming environments. The preparation of the experiment costs much less both in terms of time and money than when a new management game is developed. 
Furthermore, communication between researchers is enhanced, and results can be compared across studies.

VUMAS is a total enterprise management game tailored to the economic circumstances in the Netherlands. Although many management games in use in the Netherlands are designed with the example of an American management game in mind, there are some typical differences between management games in the U.S. and in the Netherlands.

The management games in the Netherlands differ markedly from management games in the U.S., as far as human resource management is concerned. This reflects the differences that exist between the American and Dutch economy in this regard. For example, the consequences of a lay-off are much more severe in the Netherlands than in the U.S. Firing personnel can have various consequences in management games in use in the Netherlands, ranging from a dip in productivity to strikes. In nearly every major management game in the Netherlands, poor personnel management leads to strikes, while striking personnel is virtually non-existent in most management games in the U.S., not only in total-enterprise business games, but also in functional management games aimed at human resource management.

Another major difference between management games in the U.S. and in the Netherlands is the extent to which government grants subsidies to private companies. If a company's survival is at risk, and its personnel's jobs are in danger, the government, in a management game typical for the Dutch situation, is often willing to support the company.

VUMAS has been in use at the Faculty of Economics of the Free University, Amsterdam, since the late sixties. In the seventies it was transformed from a manually administered 
game into a computerized management game. All rights to VUMAS are now held by Rematch B.V., Amsterdam, the Netherlands.

In VUMAS, a chemical company produces and markets up to 5 products. Exhibit 3-1 shows the flow of goods in this company. There are bulk products that are manufactured in two production-stages. In the first stage raw materials are processed into half products, which are consequently processed into finished products in the second production stage. Products that are made in one period can be sold in the next period. So production is planned for one period ahead. Sales projections are made two periods ahead.

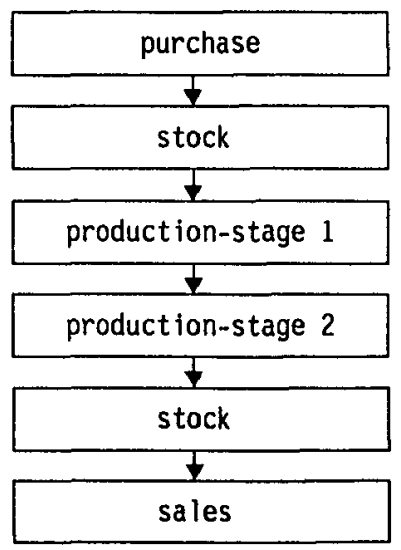

Exhibit 3-1. Flow of goods in VUMAS. 
The following decisions have to be made during every decision period (quarter of a year):

- purchase quantities of four types of raw materials or the ordering for the next four periods, requiring a total of eight decisions,

- number of units of five products to produce,

- selling price and number of units to offer of five products, one being sold on two markets, requiring a total of twelve decisions,

- personnel related variables: wage-level, training, and workplanning,

- total advertising expenditure,

- production facility expansion for two production stages,

- size of the work force at each of the two production stages,

- borrowing of short-term or long-term funds,

- payment of dividends,

- pledge for government support and

- purchase of market information.

The total number of decisions to be made every period is 37 . This number of decisions indicates the relative complexity of this game. Kasper [1983], for example, had 13 decisions per period.

As exhibit 3-2 shows, decision-making in VUMAS involves a wide variety of decisions ranging from structured to illstructured decisions. In terms of Anthony [1965] the VUMAS decisions range from operational and management control through strategic planning. Gorry and Scott Morton [1971] classified information systems on two dimensions. Exhibit 3-2 gives an overview of their taxonomy. One dimension concerns the type of problem they support: either well-structured or illstructured, see Simon [1960]. Another dimension concerns the 
type of management activity supported: operational control, management control or strategic planning, developed by Anthony [1965]. In other words, they combine two taxonomies, one given by Simon and one given by Anthony.

\begin{tabular}{|c|c|c|c|}
\hline & $\begin{array}{l}\text { Operational } \\
\text { control }\end{array}$ & $\begin{array}{l}\text { Management } \\
\text { control }\end{array}$ & $\begin{array}{l}\text { Strategic } \\
\text { planning }\end{array}$ \\
\hline Structured & $\begin{array}{l}\text { Raw materials } \\
\text { purchase and } \\
\text { ordering }\end{array}$ & $\begin{array}{l}\text { Advertising } \\
\text { expend iture }\end{array}$ & $\begin{array}{l}\text { Dividend } \\
\text { payments }\end{array}$ \\
\hline Ill-Structured & $\begin{array}{l}\text { Production } \\
\text { scheduling }\end{array}$ & $\begin{array}{l}\text { Product pricing } \\
\text { and quantities } \\
\text { offered; } \\
\text { Short term } \\
\text { borrowing; } \\
\text { Work force: } \\
\text { wage level etc. }\end{array}$ & $\begin{array}{l}\text { Plant } \\
\text { expans ion; } \\
\text { Long term } \\
\text { borrowing: } \\
\text { Government } \\
\text { grants }\end{array}$ \\
\hline
\end{tabular}

Exhibit 3-2. VUMAS decisions in the framework of Gorry and Scott Morton [1971].

\section{Simulated Time}

Simulated time in VUMAS is broken up into discrete periods (quarters), and all players submit their decisions simultaneously. Then the game program is run and the results are distributed among the players. Although most games follow this procedure, there is a notable exception: Lyons [1982] describes a game that operates in continuous time, which is more realistic. In Lyons's game, a period is still a discrete portion of time. A game period lasts for, say, a week with a new period beginning at 8:00 a.m. on Fridays. The players of the game are free to submit their decisions, for example, to change production levels, at any time during the period. If a player sets the production level of a product to 1000 units per period in the 
middle of the week, then he or she will have 500 units of that product available for sale by the next Friday morning.

\section{Output}

In each period VUMAS produces a number of standard reports, namely the ones listed in exhibit 3-3. These standard reports are produced by the transaction processing system and the management information system, incorporated in the management game: information system *2 in exhibit 2-2. Although most games produce these standard reports, Casimir [1987] plans on developing a game in which the player has to specify what types of transactions should be recorded: the standard output of the game merely consists of the raw data for the transactions. The player who thinks the amount of data is too large for manual handling, will have to build an information system to process the raw data into aggregate data. This will lead the player to pay attention primarily to a transaction processing system and management information system and only later to a decision support system. Since our research focuses on decision support systems, we distribute the standard reports mentioned in exhibit 3-3.

Profit and Loss Account

Balance Sheet

Production Report

Stock Report

Marketing Report

Liquidity Statement

Four-Period Summary

Exhibit 3-3. Standard output reports of VUMAS. 


\section{Economy and Industry Simulated}

Total enterprise games usually include some method for depicting the economy and industry within which competing teams operate. In some games a business index acts as an economic indicator; in VUMAS the total size of the market for each product indicates how the economy is doing. As in most games, the economy in VUMAS can show seasonal fluctuations, cyclical downturns and upturns, and a long term growth curve. None of the parameters of the functions simulating these developments, are disclosed to the players.

\section{Marketing/Sales}

As in most management games VUMAS gives a generic product description, defining the products only in terms of industry (chemical) and price range. The rationale for such a description is given by Scott and Strickland [1984]: "This vagueness is intentional and precludes the participant's basing his decision on the known actions of any real company." Up to five products can be marketed, one of them at two markets: the home market and the export market.

\section{Production}

Processing of the raw materials into finished goods consists of two stages, each presenting its own constraints on production volumes. These constraints are caused by both personnel and machines. Each of the five products has its own combination of ingredients (the recipe) and necessary man and machine hours. Plants can be expanded and closed, personnel can be hired and fired. Both plant and personnel changes take effect with a delay of one period. 


\section{Raw Materials Purchasing}

In many games raw materials are automatically ordered when production is scheduled. In terms of exhibit 2-2: information system *2 takes care of purchasing. However, in VUMAS ordering materials is a major group of decision variables. There are four different kinds of raw materials and they can be bought either for one shipment or for four shipments at a time. Raw materials are delivered without lead-time. The prices of raw materials can change drastically every period and some materials are only available seasonally. Therefore, purchasing requires careful planning in VUMAS.

\section{Personnel}

Besides hiring and firing, decisions must be made on wagelevel, training, and work-planning. These decisions influence the so-called personnel satisfaction indicator shown in exhibit 3-4, which influences the level of absenteeism caused by illness and hiring-costs. A low value of the indicator may lead to warning strikes and eventually to all-out strikes.

\begin{tabular}{|l|l|l|l|}
\hline $\begin{array}{l}\text { Wage level } \\
\text { Change in wage-level } \\
\text { Lay-off of > } 5 \text { people } \\
\text { Training } \\
\text { Work-planning } \\
\text { Inf luence competition }\end{array}$ \\
\hline
\end{tabular}

Exhibit 3-4. Personnel satisfaction indicator. 


\section{Finance}

In VUMAS, players are required to negotiate appropriate credit-lines from the bank, either short term or medium term. The bank requires a cash plan before offering credit. VUMAS automatically provides loans at above-normal interest rates if the firm's cash assets fall below zero. This special type of loan, often called 'emergency loan' or 'disaster loan', is a variable common among management games.

\section{Initialization}

Each team starts in exactly the same situation. While this is the case in most games, there are some games in which each firm begins with a different market share. The former has the advantage of providing each team with an equal opportunity, while the latter is more realistic. The company is in a deplorable state at the start of the game. All teams are losing money in the first period. The challenge that the teams face is finding the causes of the company's troubles and getting the company into good shape.

\section{Information on Competitors}

Each team receives full information on its own company, but may or may not be aware of how its competitors are doing. The amount and nature of information on competing teams available at the end of each round varies, depending on how much the team spends on buying information. Each firm has the option of asking for a printout of information on the environment of the firm, regarding both the raw materials market and the finished products market of the company This information must be purchased from a private research institute that conducts extensive market analysis. All these items regard market research information and carry varying price tags. Exhibit 3-5 shows which information can be bought. 
Historic information on last period's:

- number of competitors selling a particular product

- sales in units by product by competitor

- promotion expenditures in guilders

- prices they charged for the products

Projections for the next four period's:

- demand in units by product, given a certain price-level

- purchase prices of raw materials

Exhibit 3-5. Information for sale in VUMAS. 


\subsection{A Decision Support System}

In section 1.3 we defined the notion of a decision support system generator. Our study is one of the few experimental studies into decision support systems that uses a commercially available decision support system generator. The majority of experimental studies uses decision support systems that are custom-made for the management game, using programming languages such as Fortran and APL. Goslar et al. [1986] and Sharda et al. [1988] used a commercially available modeling language, namely IFPS, see Gray [1987].

There are several advantages to using decision support system generators. Compared to programming languages, they offer more 'power' and flexibility through ease of use and an ability to better understand and modify the model relationships. Development time and costs of the decision support system are minimized. If a decision support system is used which is machine-specific or unpublished, it is difficult for other researchers to make replications and comparisons of studies. Communication between researchers is enhanced, and results can more easily be compared across studies.

\subsubsection{DEVELOPMENT OF THE SPECIFIC DECISION SUPPORT SYSTEM}

Using a decision support system generator, a specific decision support system was developed by participants of the VUMAS management game. The participants were graduate students in Information Systems at Delft University of Technology, the Netherlands. During an eight-week course in Decision Support 
Systems, they were required to submit one period's decisions for VUMAS every week. Objective of the exercise was the development of a system to support the decision-making in VUMAS in order to use it for preparation of the weekly decisions. Obviously, the decisions made during the first couple of weeks were primarily based on manual calculation. Later in the course decisions were increasingly made with support of the decision support system that the decision-makers themselves were building simultaneously.

In order to make a selection between available decision support system generators, different groups of students used different decision support system generators: Comshare's System W (on both PC and mainframe), Lotus 1-2-3, Micro-FCS, IFPSPersonal and Javelin. Based on the experiences of the teams and the quality of the systems built, Javelin was selected as the most appropriate decision support system generator for this problem situation. Later this selection was confirmed by a comparison made by Swaab-Dekker [1987]. She evaluated decision support system generators, giving them scores on a number of criteria as listed by Reimann and Waren [1985]. Applying the weighted ranking by levels-method, described by Sharff [1969], she concluded that Javelin came out top for this particular problem situation (VUMAS). A major weakness in weighting and rating-methods, however, is the subjectivity of the evaluation-rates and the weightings attached to these evaluationrates.

A decision support system provides a variety of levels of support. Keen and Scott Morton [1978, p. 97] distinguish four levels. A decision support system includes capabilities which provide each of these four levels of decision support to a certain degree. We describe the decision support on these 
levels in order of increasing support. The first level is access to facts or information retrieval. The decision support system used in our experiment provides insight into the historical data, which would otherwise be an inaccessible mess of raw data. The second level is the addition of filters and pattern recognition ability to this data retrieval. Examples are the graphics and time-series analysis provided by the decision support system used in our experiments. The third level distinguished by Keen and Scott-Morton are simple computations, comparisons, and projections. The decision support system executes a number of calculations, such as interest payments and taxes and brings information together to enable comparisons. The final level of support provides useful models to the manager. This is in fact the most important level of the decision support system. It enables the decision-maker to do "what-if" analyses.

\subsubsection{JAVELIN}

Javelin is a financial planning and analysis program, see Javelin [1987]. It qualifies as a decision support system generator, since it is an integration of a number of decision support system-tools: spreadsheets, statistical functions and database management functions.

A key feature of Javelin is its advanced user interface. Javelin works with the concept of views. Each view offers a special way of communicating between user and system.

The most important of these views are the following: 


\section{Diagram view}

A flow chart shows how a variable is related to other variables in the model. For any given variable it shows the variables that directly affect that variable and the variables that are directly affected by that variable. This view is useful for understanding the logic of the model.

\section{Formulas view}

Shows all formulas in the model.

\section{Spreadsheet view}

Shows a spreadsheet of rows and columns. By entering variable names and dates in the spreadsheet borders, the corresponding data appear in the spreadsheet cells. The spreadsheet view is important for entering data and for preparing reports.

\section{Graph view}

Shows a graph of the values of one or more variables. The graphs can be of a wide variety of types.

Almost any view can be used to change information contained in the data subsystem and the model subsystem. Javelin automatically reflects the changes in the other views. Each view is a different way of looking at the model base and the database. For example, the user can define a variable in one view and simultaneously see how that variable connects to others in another view. 


\subsubsection{DECISION SUPPORT SYSTEM DESCRIPTION}

An extensive description of the specific decision support system developed in Javelin is given in Van Schaik [1988]. A user manual is given by Fung-A-You and Plompen [1987]. Here we give only a concise description of the system.

All spreadsheets and graphics to be described in this section can be reached via simple menus. The main menu features the options, shown in exhibit 3-6. Exhibit 3-7 shows the spreadsheets submenu and exhibit 3-8 shows the graphics submenu.

\begin{tabular}{l}
\hline Main menu \\
\hline Importing data from game program (via diskette) \\
Printing the decision forms (to be submitted to game \\
leadership) \\
Spreadsheets submenu \\
Graphics submenu \\
Save model and data; quit \\
\hline
\end{tabular}

Exhibit 3-6. Main menu of the Decision Support System. 


\begin{tabular}{|l|}
\hline Spreadsheets submenu \\
\hline Marketing/Sales \\
Production \\
Raw Materials Purchasing \\
Personnel \\
Credits \\
Cash statement \\
Profit and Loss Statement \\
Balance-sheet
\end{tabular}

Exhibit 3-7. Spreadsheets submenu.

\begin{tabular}{|l|}
\hline Graphics submenu \\
\hline Sales \\
Production and stocks \\
Profit \\
Personne I \\
Cash \\
Income \\
\hline
\end{tabular}

Exhibit 3-8. Graphics submenu.

Information is presented and input values are entered into a number of spreadsheets. Information pertinent to a functional area is combined on a single spreadsheet. 


\section{Marketing/Sales}

For each of the five types of finished products this spreadsheet gives information to show how many units are available for sale, given the planned production. Historical information is given on sales-levels. Input values can be entered here on how many units will be offered, on which market, at what asking price. The expected sales in Dutch guilders are calculated.

\section{Production}

For each of the finished products this spreadsheet gives the minimum production level in the next period, needed for the projected sales level. Also, historical information is given on the actual production levels. Currently available production capacity of men and machines is shown and, if needed, expansion of production capacity is proposed. Input values to be entered in this spreadsheet are the production levels for all products and changes in machine production capacity: purchasing or scrapping of machines.

\section{Raw Materials Purchasing}

For each of the four types of raw materials, information is given regarding the purchase quantities necessary, given the numbers in stock and the planned production. Input values to be entered in this spreadsheet are purchase quantities and the number of shipments in which the order should be delivered (either one or four).

\section{Personnel}

For each of the two production phases this spreadsheet gives the number of employees needed for the planned production levels. Input values can be entered into this 
spreadsheet, showing number of people to hire or to lay off and the wage-level. Total personnel outlay is calculated.

\section{Loans}

Information is given on short term, medium term and disaster loans: both the loan amounts and the interest rate are displayed.

Another three spreadsheets contain information only useful in running the company; no input values can be entered into these spreadsheets. These spreadsheets are the balance-sheet, the profit and loss statement, and the cash statement.

A key characteristic of Javelin is that all these spreadsheets are linked. So, after entering a value into one spreadsheet, any dependent value in other spreadsheets is automatically adjusted. Some relations between the spreadsheets are shown in exhibit 3-9. 


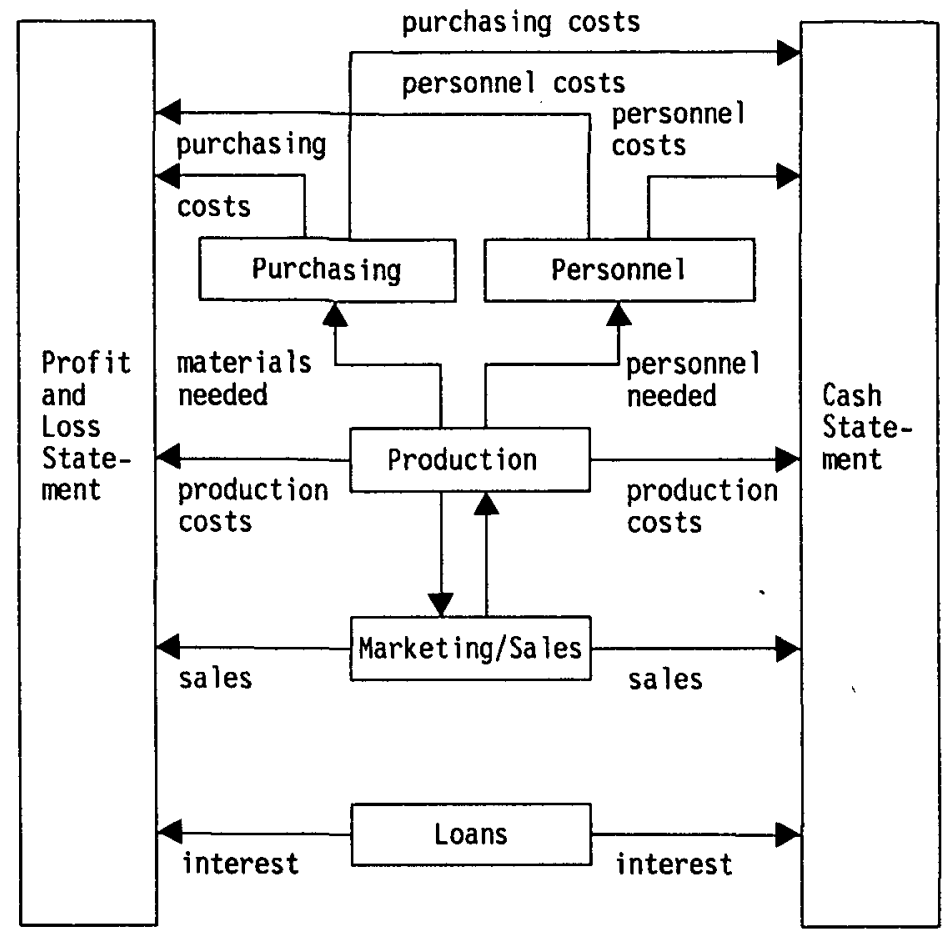

Exhibit 3-9. Flow of information between spreadsheets.

For example, when sales projections are made for two periods ahead, and entered into the sales spreadsheet, then relevant information on the production spreadsheet changes too. This information includes 'needed production quantities'. These quantities are calculated from the sales projections and the available products in stock. When deciding on allocation of the production facilities to the different products, information such as 'needed production quantities' is very helpful. Much more of this kind of information is given, such as needed plant increases for the two production stages. 
Helpful information is offered the other way around too. When production planning is entered as input values into the production spreadsheet, adjustments in the sales spreadsheet are made automatically. One of these adjustments concerns the variable 'finished products available for sale'. Once production decisions are made, this information is very helpful when a team is deciding on the quantities of finished products offered on the market. So, there is a two-way flow of information between these sheets.

Two spreadsheets are linked to the production spreadsheet in a similar way. These are the purchasing spreadsheet and the personnel spreadsheet. On the purchasing spreadsheet information is given about the quantities of raw materials needed for the planned production. These quantities are calculated using the input values entered into the production spreadsheet, the formulas for the finished products, and the quantities of raw materials in stock.

The personnel spreadsheet gets its information also from the production spreadsheet. It states how much personnel should be hired and what training this personnel should receive. This takes into consideration production levels and plant increases.

The spreadsheets contain both historical values and leastsquares predictions of variables. The user can calculate the least-squares regression line with either time or any other variable as the explanatory variable.

Another view often used in the decision support system is the graph view. It is possible to show all variables in many types of charts, for example, the bar chart. Unlike bar charts in 
other packages, however, this chart lets the user enter and edit data. By using arrow keys he can change the size of bars for input variables, thus altering the data in the database.

Over a time period of $11 / 2$ years the specific decision support system was amply tested and gradually improved. The VUMAS management game with decision support from the prototype system was played at several institutes, including the Free University at Amsterdam and the Nijenrode Business School at Breukelen, the Netherlands. Improvements were made continually, prompted by the experiences gained by players, who were primarily graduate students in business and business economics. Eight versions of the decision support system were developed and subsequently tested by players. Finally, a system resulted with which the experiments of this dissertation were carried out, see Van Schaik [1988]. 


\subsection{A Decision Strategy}

To be able to describe a decision strategy, we make a distinction between equation models and process models. These two types differ in a number of respects. In an equation model time is split up into intervals of constant length. The state of the system at the end of every interval is computed using difference equations. A typical example of an equation model is a corporate model, which has equations like:

cash at end period $=$ cash at begin period + receipts-expenditures and

stock keeping costs $=0.5^{*}$ number of products in stock

In equation models one has to define functional relationships in terms of definition equations (such as the first of the above equations) and behavioral equations (such as the second of the above equations). Although these equations may be specified in a non-procedural way, they still apply to the outside of a phenomenon, seen as a black box.

Process models represent individual events in the real-world system in great detail. An event is defined by Kleijnen [1980, p. 140] as a change in the system's state, for example, the arrival of a customer. In process models time is not cut into equal slices; instead the program jumps from one event to the next. In process models one does not try to summarize a process in equation form. Instead, one tries to describe the sequence of activities, using events in the real-world system. A special type of process models are discrete event simulation models. 
The description form we use when describing a process of decision-making is the process model and not the equation model, see Sol [1987]. One of the advantages of the process model is that this type of model allows a much more realistic modelling of the problem situation. Another advantage is that the user can understand a process model better than an equation model.

For both equation models and process models, however, the ability to generalize the results is limited, because the outcome of the model is only valid for the specified values of input variables and parameters.

During pilot experiments participants were asked to develop a decision strategy for the VUMAS managament game. There were wide-ranging differences in these decision strategies. One of the typical differences is between a production-driven and a marketing-driven strategy. In a production-driven strategy the decision-maker starts with an optimal planning of the production facilities and subsequently plans the marketing of the products.

The decision strategy used in the experiments is designed by an expert in the field and has been checked by another expert. Both experts have a longstanding experience in academia and business. The decision strategy has been amply pre-tested in pilot-studies, conducted among students at Delft University of Technology. A total of 65 students attending the courses Decision Support Systems and Business, participated in the management game described in section 3.1, aimed at testing the decision strategy and the decision support system described in sections 3.2 and 3.3. Prompted by their comments, we finetuned the decision strategy. After subsequent use of the decision strategy no suggestions for further improvements were 
received. The decision strategy has been validated in this sense.

The decision strategy is presented in exhibit 3-10. Next we describe the steps in the decision strategy. 


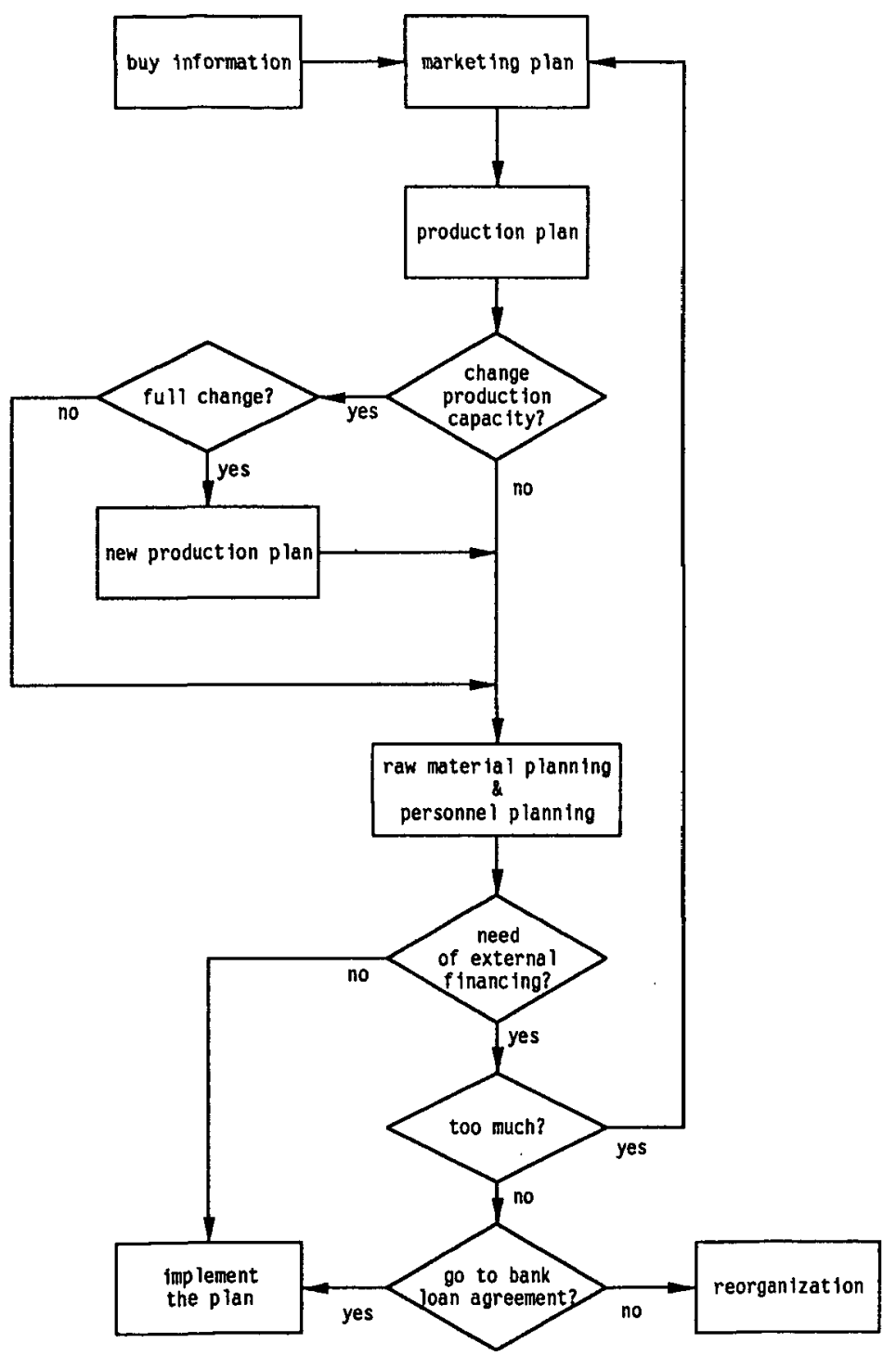

Exhibit 3-10. A decision strategy. 
The first step is the purchase of market research information (in the form of reports) and the subsequent analysis of it. This information concerns the markets for finished products (size of the markets at a certain price-level and actions of the competitors), and the market of raw materials (pricedevelopments).

Next comes the marketing planning, which starts with the consideration to enter new product markets and to withdraw from current product markets. It further includes changes in pricing policy, and determination of advertising expenditures for more effective penetration of the company's market. This planning activity produces the marketing plan, which is in fact the strategic plan of the company.

After setting the marketing plan, the next step is the production planning, i.e. determining the production quantities needed to realize the marketing plan.

Next the production facilities planning, directed toward adjustment of the production capacity and consideration of actions taken to utilize excess capacity where available (most often in production phase 1 ).

The production plan leads to the personnel plan (projection of personnel requirements in the two production phases, determination of wage level, social work and training) and the purchase plan (calculation of raw materials quantities necessary and timing of purchase).

The above types of planning deliver input to the financial plan. It consists of the projection of sales by product, gross profit 
(sales minus manufacturing costs) by product, sales and general and administrative expenses, net profit by product, working capital needs, return on investment by product, and comparable financial analyses and ratios.

The financial planning might lead to negotiations with the bank. The bank can either grant the loan or decide that the capital requirements are too large. In the latter case a complete overhaul of the marketing plan may be necessary, subsequently leading to an overhaul of the other plans.

At several points in this strategy there are feedback loops.

This strategy is normative. It is a prescription for the sequence of steps in the decision-making process. However, it is not a formula on how to make the best decisions in VUMAS. For example, it does not suggest to expand production capacity with a specific amount or set the prices at a particular level. It prescribes which steps a decision-maker should take. It gives the sequence of the decisions.

A decision-maker can follow the decision strategy, whether he uses a decision support system or not. 


\subsection{Experimental Design and Treatments}

As described in section 2.1 we test the hypotheses using the gaming approach. Basically, the experimental method consists of the determination of contrasts between treatments. The subjects in these treatments are treated identically, except for one feature that is different. We refer to this difference as the experimental treatment, the independent variable or the factor. The manipulation of this independent variable is under control of the experimenter. Numerous aspects of the performance of the subjects are measured and recorded. Any difference that we observe for the dependent variable is called the treatment effect and is assumed to have been caused by the experimental treatment. The most important feature of the experimental method is that it is possible to infer a cause-effect relationship. That is, we can conclude that the difference we observe in the performance of the subjects was caused by the experimental treatment.

CONTROL OF NON-TREATMENT VARLABILITY

In an ideal experiment, we can treat the subjects exactly alike in every respect except for the necessary variation of the independent variable. Unfortunately, this ideal experiment is never performed in real life. That is, it is virtually impossible to conduct an experiment where the only difference among treatment groups is the experimental manipulation. Nonetheless, we are still able to conduct experiments and to draw meaningful conclusions from them. We accomplished this in the following way. 
First, certain features were held constant across the levels of the experiment. All of the testing was done in the same buildings (Koninklijke Jaarbeursgebouwen, Utrecht, the Netherlands), by the same experimenter and the same support staff, and with the same equipment (IBM-compatible personal computers) and testing procedures. Even more important, the management game as described in section 3.1 was the same for all participants. Each has the same competitors, because of the phantom firms, which will be described in section 3.6.

Second, control of other features of the experiment, though not absolute, is sufficiently tight to make these features essentially constant. Consider, for example, the number of members per team, varying between 3 and 4 . This variation is sufficiently small to allow us to view the number of team-members as constant, see Gentry [1980]. Even with these features controlled, however, many variables remain uncontrolled and they influence the behavior we are studying.

There is another major source of uncontrolled variability present in any experiment, namely, the difference in performance among subjects. One obvious way to hold subject differences constant is to use the same subject in each treatment condition. However, there are potentially serious carry-over effects from one treatment to another owing to the successive assignment of the different treatments to the same subjects. People usually learn from their experience. So, if they solved a problem under a certain treatment, they will remember how to solve that problem when they are assigned to another treatment. The observations would show systematic learning effects. Therefore, subjects are assigned to one treatment only. 
There is a third method to control independent variables that might influence the variables that we are studying. It consists of the elimination of systematic differences among the treatment conditions by means of randomization. In our experiment the elements forming the statistical population are people. Even though we minimized the differences in experience and background in the way described above, the responses of people may show relatively large variability due to differences in subject characteristics, such as motivation and attitude. In order to increase the sensitivity of the experiment we try to separate the latter source of variability from treatment effects and experimental error, as follows. We randomly assign 90 subjects to 23 teams (consisting of three or four members), and randomly assign teams to treatments. In this way, the different subjects have the same probability at the beginning of the experiment of being assigned to any one of the treatment levels. By following this procedure with many subjects, we eliminate any systematic effects connected to the subjects in which we are not interested.

\section{TREATMENTS}

The hypotheses of section 2.2 indicate which treatments we should administer to the teams.

Hypothesis 1 concerns the factor use of a decision support system. To test this hypothesis, teams should be assigned to either one of two treatments. These two treatments are:

- use of a decision support system,

- use of paper, pencil and pocket calculator only. 
Hypothesis 2 concerns the factor decision strategy consisting of a prescribed order of making decisions as described in section 3.3. To test this hypothesis teams should be assigned to either one of the following two treatments:

- use of the decision strategy,

- no use of the decision strategy

So the treatment conditions are formed by the two levels per independent variable; there are two independent variables, so there are four treatment combinations: without decision support system/without decision strategy, with decision support system/without decision strategy, without decision support system/with decision strategy, and with decision support system/with decision strategy. These four treatments are presented in exhibit 3-11, including the number of teams that we randomly assigned to each treatment. Every team serves in only one of the four treatments, as explained above.

\begin{tabular}{|l|c|c|c|}
\cline { 2 - 4 } \multicolumn{1}{c|}{} & with DSS & without DSS & \multicolumn{1}{c|}{} \\
\hline with strategy & 6 & 5 & 11 \\
\hline without strategy & 6 & 6 & 12 \\
\hline \multirow{2}{*}{} & 12 & 11 & 23 \\
\hline
\end{tabular}

Exhibit 3-11. Number of groups under the $2 \times 2$ treatments.

Our experimental design is a so-called factorial design, i.e. the experiment includes every possible combination of the levels of the independent variables. Exhibit $3-11$ is the so-called factorial matrix. Each level of the factor "use of decision support system" is combined with each level of the factor "use 
of decision strategy." In other words, the independent variables are completely crossed.

The advantages of the factorial design are twofold: economy and measurement of interaction effects. If we would manipulate the variables in two separate single-factor experiments, we would be able to make statements concerning the influence of the use of decision support system on decision quality and separately, statements concerning the use of decision strategy on decision quality. However, given the number of subjects participating in the experiment, these statements would be based on fewer observations, because every team can be assigned to one treatment only. The economy of the factorial design represents a distinct advantage over separate singlefactor studies.

Another advantage of the factorial design is the measurement of interaction effects. Interaction means that the effects of one of the independent variables (e.g. decision support system) are not the same at each of the levels of the other variable (decision strategy). The factorial design enables us to determine something that is not obtainable from the single-factor experiment, namely, the unique manner in which the two independent variables jointly influence behavior, see Kleijnen [1987, p. 260] for a discussion of the merits of the factorial design versus the "one factor at a time" approach.

In the above design, a single observation per subject per treatment combination can be analyzed. For example, for each team we calculate the total profit for all seven periods, which is a measure of the performance of the team during the whole experiment. However, data regarding profit are available for each period that the team participates in the experiment. If we 
view our experiment in this way, we can call the different periods that the teams play, repeated measurements on the same subject. Experimental designs in which subjects receive more than one treatment are called designs with repeated measures. Winer [1971] gives a discussion of the statistical aspects of this design. Cole and Grizzle [1966] give a number of applications of repeated measurement designs and LaTour and Miniard [1983] warn against possible pitfalls. In these terms, we have a $2 \times 2 \times 7$ two-factor repeated measures experimental design. We let the teams play 7 periods instead of one period, because it takes some time for the difference in independent variables to take effect. It is essentially the same reason why we let the participants play a management game and do not let them solve a case-study (see section 2.1). The same teams participating in a number of rounds of play leads to a design with repeated measures instead of a full factorial design with independent replications; the latter design is described by Kleijnen [1987, p. 261]. 


\subsection{Subject Population}

In a game, the players either play simulated roles or they play themselves. For example, one might have a management game in which a student is instructed to behave as though he were the president of General Motors. In that case, he is playing a simulated role. In a military exercise a major may either be required to simulate the role of a general, or to play his own role of a major, see Shubik [1975, p. 7]. In the overwhelming majority of management game studies, the subjects participating in the experiments are university students playing the role of managers of a company; see Remus and Kottemann [1987], Volonino et al. [1987], Dos Santos and Bariff [1988]. Some use graduate students, see Lucas and Nielsen [1980] and Benbasat and Schroeder [1977]; some even use undergraduate students, see Lusk and Kersnick [1979] and Remus [1984]. However, students are only surrogates for the 'real' decision support system user population. Therefore, we recruited a total of 90 managers with substantial experience in business. They are middle-level managers from a variety of Dutch companies, with job titles such as controller and head of financial department.

All managers were enrolled in a two-year part-time postexperience course in the financial accounting field. The course is part of the continuing education program of the Netherlands Institute for Management (NIVE). Because of the admission requirements for the course and the near completion of the course at the time the management game was played, all the subjects had the theoretical and practical background needed to perform the experimental task. The management game is an integral component of the one but last semester of the course. 
The management game is a compulsory part of the course, and during the lessons the teacher frequently applies the classroom knowledge to the management game. In order to motivate the subjects a monetary incentive scheme was used, see Benbasat et al. [1986, p. 1100]. Small monetary prizes were awarded to the top performing teams. 


\subsection{Procedures}

Game descriptions were mailed to the participants two weeks before an introductory session was held. This introductory session lasted for two hours and was attended by all participants. One hour was devoted to the presentation of the game and another hour was devoted to the introduction of the decision support system. The decision strategy was presented during a separate session, attended only by the subjects assigned to the decision strategy treatment. They were instructed not to disclose the decision strategy to the other participants of the experiment.

Two test periods were played. One test period was played to acquaint the participants with the task environment, i.e. the management game, without use of the decision support system. Another practice session was intended to further familiarize all subjects with the operation of the management game, and to acquaint a number of subjects with the decision support system. This helped to remove some learning from the experimental session by giving the subjects familiarity with the report formats and input/output procedures.

Each team's play began from the same set of initial conditions. All game parameters during the play, such as development of industry demand levels and raw material prices, were identical for all teams. The nature and amount of information provided by the computer printouts, was the same for all groups, independent of their treatment.

The experiment was conducted during a two-month period with weekly or bi-weekly sessions. At the end of each session, the 
teams submitted the period's decisions to the game administrator. The game administrator and his staff then entered all decisions into the computer, the game program simulated the quarterly performance, and results were presented to each team at the start of the next session. A limited feedback by the game administrator was given at the beginning of each round of play.

For each of the seven decision rounds, the teams were given $11 / 2$ hours to make their decisions. This fixed duration of the game periods reduces experimental noise.

The subjects were not told of the specific nature of the experiment. The course instructor informed the players that the experimenter would be the game administrator. In order to minimize the effect of 'end-of-game' strategies, the subjects were not told the precise game duration in advance.

One modification was made to the game for the purposes of the experiment. The original game was designed to be played by competing teams, who collectively formed an industry. However, in that case the performance of a team is a function of the other teams, making tight experimental control impossible. Accordingly, the concept of phantom companies was developed ${ }^{1}$. Each real team in the experiment was placed in a separate 'industry', independent of the other real players. Four phantom companies were created for each industry. All decisions (during 7 periods) for these phantom companies was preset by the experimenter. Thus, each team in the experiment faced the same set of four phantom companies in the industry,

1. We are grateful to Gordon B. Davis for recommending the development of phantom firms. 
enabling control to be maintained over the experimental environment. This approach was followed before, for example, by Lucas and Nielsen [1980].

During every period of play the output data from the game (marked II in exhibit 2-2) are written on a diskette and handed over to the teams, who load them into their Javelin program on their PC. Thus, the teams get an updated history of their company after each round of play. This diskette contains the same data that, are given to all teams on paper. So the teams not using a decision support system, get output only on paper, and teams using a decision support system get output both on paper and on floppy disk. 


\subsection{Independent and Dependent Variables}

Categories of variables available for measurement in this study include the use of a decision support system, and the use of a prescribed decision strategy, and various company performance indicators.

\section{INDEPENDENT VARIABLES}

There are two independent variables. One independent variable is the decision support system. The treatment is at two levels: available or not available. A decision support system as described in section 3.2, is given to the 'available' treatment group. The control group has no decision support system available; teams in this group prepare their decisions using paper, pencil, and pocket calculator only.

The second independent variable in our research is the decision strategy. This strategy is described in section 3.3.

\section{DEPENDENT VARLABLES}

The dependent variables are measures that indicate the contribution the independent variables (decision support system and decision strategy) offer to the quality of the decisionmaking. This way the decision support system and the decision strategy can be evaluated.

There is a plethora of articles published on the evaluation of information systems, (see King and Rodriguez [1978], 
Matlin [1979], Ahituv [1980], Hamilton and Chervany [September 1981], Hamilton and Chervany [December 1981], Chandler [1982], Fuerst and Cheney [1982], Srinivasan [1985]) and of decision support systems in particular, see King and Epstein [1983], Aldag and Power [1986], Goslar et al. [1986], Pieptea and Anderson [1986] and Dos Santos and Bariff [1988]. In these articles many different measures have been used for evaluation. We propose a framework that brings some structure into this myriad of measures. This framework is based on the distinction made by Bosman [1977] between the decision-making process, the actual decision, the implementation of that decision and finally, the results of that decision. We described this distinction in section 1.2 and showed the various stages in exhibit 1-1.

From section 1.2 it follows that evaluating a decision support system basically means determining its effectiveness. Determining the effectiveness of a decision strategy is not basically different from determining the effectiveness of a decision support system: the following analysis is applicable to any aid used in the decision-making process.

Determining the effectiveness of a decision support system should ideally be done by measuring aspects of behavior (2) in exhibit 1-1: Do the results of the decisions improve because of the use of a decision support system? For example, does the company make more profit now that decision support systems are used? However, there are many more influences on behavior (2) than just the decisions made, for example, behavior of competitors.

That is why it is often very difficult to determine the influence action (1) has on behavior (2), and subsequently trace the 
influence of the use of the decision support system on behavior (2). For that reason often surrogate measures are chosen to evaluate the decision support system. Instead of measurements based on the results of the decisions, measurements based on the decision-making process, i.e. action (1), or on the decisions made, i.e. behavior (1) can be used in the evaluation. We first give an analysis of possible measures and next describe the performance measures we chose.

\section{Decision-making process variables}

The first category of measurements are decision-making process variables, i.e. variables based on action (1). Various aspects of the decision-making process can be measured. Within this category a distinction can be made in three groups of variables: quality of the decision-making process, time spent in reaching a decision and confidence in the decision. Measurements in the first group include number of alternatives evaluated and various forecast errors.

Number of alternatives examined is one of the most common measurements in this category. Dickson et al [1977], Gallupe [1986], Kasper [1985], Eckel [1983], Goslar et al. [1986], Cats-Baril and Huber [1987], Sharda et al. [1988] all use the number of alternatives as one of the performance variables.

Kasper [1985] sees the ability to accurately forecast the results of decisions as critical to effective decision-making. Hence, he chooses the mean absolute forecasting error of stock price, market share and return on assets as the performance indicators. 
Time spent in reaching a decision is analyzed by Benbasat and Schroeder [1977], Benbasat and Dexter [1982], Goslar et al. [1986], Sharda et al. [1988].

Confidence in the decision is analyzed by McIntyre [1982], Goslar et al. [1986], and Cats-Baril and Huber [1987].

Variables based on action (1) all have one drawback in common: if some measure has a better score, it does not necessarily mean that it leads to any better results in dependent variables. There is no monotonic relationship between the measures and the goal. Keen [1987] states: "Looking at more alternatives is not a causal force for improving decision- making. Why should one expect better decisions by allowing a stupid person to look at more bad options and draw wrong conclusions more quickly?"

\section{Decision-quality variables}

A second category of measurements consists of variables based on the quality of the decision, i.e. variables based on behavior (1). This variable is particularly hard to measure, since the evaluation has to weigh all circumstances under which the decision is made. Gallupe [1986] chooses decision quality as one of the prime performance variables. In his experiment, decision quality is measured by a panel of experts who evaluated the decision made by each participant based on criteria that the experts had agreed on prior to the actual running of the experiment. Joyner and Tunstall [1970], King and Rodriguez [1978], Aldag and Power [1986], Cats-Baril and Huber [1987] also had the quality of decisions in a management game assessed by a number of raters. These experiments demonstrated that this approach is reliable in terms of evaluation decision quality. 


\section{Decision-outcome variables}

A third category of measurements consists of decision-outcome variables, i.e. variables based on behavior (2). Typically, measurements in this group include market share, profit and cost. Benbasat and Schroeder [1977] use cost as a performance variable. Often a linear combination is chosen of market share, inventory performance, profit performance, share price etc. Chakravarti et al. [1979], Eckel [1983], Sharda et al. [1988] use profit as the performance indicator. Lucas [1979] calls profitability the standard measure for performance evaluation in a management game. According to Hand and Sims [1975], using profit as a performance indicator has the advantage of maintaining a strong degree of relevance between the game and reality. Critics of the profit-performance approach, however, maintain that profitability in a game is more a function of some random element than the result of high quality decision-making.

Hand and Sims [1975] and Lucas [1979] try to find some middle ground between the extremes of performance measurement based on action (1) and behavior (2). Hand and Sims developed a multi-dimensional measurement of performance comprising 6 measures based on action (1) and 7 measures based on behavior (2). After experimentally establishing which performance variables showed significant relationships with each other, they were able to eliminate all but two variables, one from each group. Thus, they found that their list of performance variables boiled down to sales forecast error as the primary 'driving' variable and profit as the primary 'end result' variable. 
In our study the measures of success consist of the total profit made during all periods, the average profit per period and a composite company performance score. These three measures are automatically computed for each company by the game program.

Total company profit serves as a measure of overall success during all periods of the experiment. Profit per period indicates whether there is any development in the quality of decisions. For example, decisions may be good for a decisionmaker in the early rounds of play and gradually deteriorate over time.

The composite company performance score is a weighted average based on profit, utilization degree of the production capacity, price setting behavior, finance, personnel, dividends and information policy. The composite company performance score (on a 1-10 scale) is based on the elements listed in exhibit 3-12. The score for the information policy is determined by the number and the relevance of the information items bought by the company.

As an example, the results for a typical team is given. At some of the institutes at which VUMAS is playcd as a compulsory part of the curriculum, this composite company performance score is used to determine the marks the participants get as a grade for the course.

The performance score has one value for each team, and is a measure for the overall quality of the decisions, made during all quarters combined. This means it does not show if decisions are worse in the initial periods and better later on. The performance score is an aggiegated measure: it evaluates 


\section{Sec. 3.7 INDEPENDENT AND DEPENDENT VARIABLES}

quality of the decisions made by the team from the first quarter through the last quarter.

\begin{tabular}{llrrr} 
& Element & Score & Weight & Points \\
\hline Behavior (1) & $\begin{array}{l}\text { Information } \\
\text { policy }\end{array}$ & 5 & 2 & 10 \\
& Dividend policy & 8 & 1 & 8 \\
\hline Behavior (2) & Profit & 10 & 1 & 10 \\
& $\begin{array}{l}\text { Profit per } \\
\text { production unit }\end{array}$ & 10 & 1 & 10 \\
& $\begin{array}{l}\text { Personnel } \\
\text { Satisfaction }\end{array}$ & 2 & 2 & 4 \\
& $\begin{array}{l}\text { Indicator } \\
\text { Warning strikes }\end{array}$ & 10 & 1 & 10 \\
& Strikes & 10 & 1 & 10 \\
& Shortage demand & 5 & 2 & 10 \\
& Surplus demand & 3 & 2 & 6 \\
\hline Total & Emergency loan & 9 & 1 & 9 \\
\hline & Bankruptcy & 10 & 3 & 30 \\
\hline
\end{tabular}

Exhibit 3-12. Elements of the composite company performance score: an example. 


\section{ANALYSIS OF THE EXPERIMENTAL}

\section{FINDINGS}

This chapter presents an analysis of the results of the set of experiments. First, the results of decision support system use, are presented. Second, the effects of the use of a decision strategy designed by an expert, are presented. Third, the effects of the independent variables are presented. Fourth, an overview of the results is given.

We report the results of the usual method of hypothesis testing based on a level of significance of 0.10 . We also report the plevel, that is the $\alpha$-value at which the result would have become insignificant. This method allows each reader to judge the strength of the results according to his own standards. The relationship is stronger as the p-value gets smaller.

Some of the teams failed to turn in their decisions during the last one, two or three periods of play. Thus, their team decisions are missing for these time periods, and it resulted in a smaller sample size for those periods: missing data problem. The exact sample size used to compute the statistics is noted in all exhibits. The actual number of teams per treatment per period is given in exhibit 4-1. 


\begin{tabular}{|c|c|c|c|c|c|c|c|}
\hline & \multicolumn{7}{|c|}{ period } \\
\hline & 1 & 2 & 3 & 4 & 5 & 6 & 7 \\
\hline without strategy, without DSS & 5 & 5 & 5 & 5 & 5 & 5 & 5 \\
\hline without strategy, with DSS & 5 & 5 & 5 & 5 & 4 & 2 & 2 \\
\hline with strategy, without DSS & 6 & 6 & 6 & 6 & 6 & 5 & 5 \\
\hline with strategy, with DSS & 7 & 7 & 7 & 7 & 7 & 7 & 7 \\
\hline total & 23 & 23 & 23 & 23 & 22 & 19 & 18 \\
\hline
\end{tabular}

Exhibit 4-1. Number of teams under the $2 \times 2$ treatments during 7 periods.

RESULTS CONCERNING

DECISION SUPPORT SYSTEM

Hypothesis 1 concerns the decision support system main effect, i.e. the difference in performance between the decision support system users and the non-users (aggregated over the other factor, decision strategy).

The first analysis uses Student's t-test to determine the effect of a decision support system on the dependent variables. The t-test, its assumptions and its applications in simulation are discussed in Kleijnen [1987, p. 14]. The dependent variables consist of the comprehensive company performance score, described in section 3.7, and the total profit of the simulated company. The results of the analysis are shown in exhibits 4-2 and 4-3. The number of groups is based on period 1 . 


\begin{tabular}{lcc} 
& no DSS & OSS \\
\hline number of groups & 11 & 12 \\
average score & 5.75 & 5.85 \\
standard deviation & 1.47 & 1.65 \\
minimum score & 3.33 & 3.67 \\
maximum score & 7.66 & 7.94 \\
\hline
\end{tabular}

Exhibit 4-2. Effect of decision support system on company performance score.

The calculated value of $\mathrm{t}$ for the difference in the composite performance score is -0.15 with $n_{1}+n_{2}-2=11+12-2=$ 21 degrees of freedom (assuming common $\sigma^{2}$ ), which is not significant, not even at $\mathrm{p}<0.10$. This means that the decision support system users did not perform better than the nondecision support system users with respect to the composite performance score.

A similar pattern of results is observed using total company profit (summed over all periods) instead of the company performance score, see exhibit 4-3. The calculated value of $t$ is 0.42 with 21 degrees of freedom, which is not significant, not even at $p<0.10$. This means that the decision support system users did not perform better than the non-users with respect to company profit. 


\begin{tabular}{lrr} 
& no DSS & DSS \\
\hline number of groups & 11 & 12 \\
average profit & $-1,684$ & $-2,046$ \\
standard deviation & 1,418 & 2.476 \\
minimum profit & $-3,820$ & -6.919 \\
maximum profit & 929 & 683 \\
\hline
\end{tabular}

Exhibit 4-3. Effect of decision support system on total company profit.

The performance score of a team is an indicator of the overall quality of the decisions made during all periods played by that team. The total company profit, however, is influenced by the number of periods actually played by the team. Therefore, the latter indicator may be biased by the teams that played less than 7 periods, the former not.

A second analysis evaluates the difference in performance of the teams during each quarter separately. In each period we compare the profit of the teams with and without a decision support system. In exhibit 4-4 we present the results of this analysis. In nearly all periods company profit averaged over is negative, reflecting one of the basic traits of the game, described in section 3.1: players are required to reverse the results of a failing company.

The results are illustrated in the graph shown in exhibit 4-5. 
Ch. 4 ANALYSIS OF THE EXPERIMENTAL FINDINGS

\begin{tabular}{|c|c|c|c|c|c|c|c|}
\hline & no DSS & - & DSS & -... & differ & ence & \\
\hline $\begin{array}{l}\text { per- } \\
\text { iod }\end{array}$ & mean s.d. & $\mathrm{nr}$. & mean s.d. & $n r$. & $\begin{array}{l}t- \\
\text { value }\end{array}$ & d.f. & significance \\
\hline $\begin{array}{l}1 \\
2 \\
3 \\
4 \\
5 \\
5 \\
6 \\
7\end{array}$ & $\begin{array}{ll}-307 & 245 \\
-433 & 171 \\
-317 & 209 \\
-151 & 344 \\
-163 & 289 \\
-241 & 454 \\
-181 & 390\end{array}$ & $\begin{array}{l}11 \\
11 \\
11 \\
11 \\
11 \\
10 \\
9\end{array}$ & 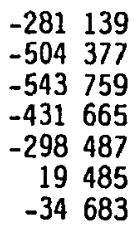 & $\begin{array}{r}12 \\
12 \\
12 \\
12 \\
11 \\
9 \\
9\end{array}$ & $\begin{array}{r}-0.31 \\
0.57 \\
0.95 \\
1.24 \\
0.79 \\
-1.21 \\
-0.56\end{array}$ & $\begin{array}{l}21 \\
21 \\
21 \\
21 \\
20 \\
17 \\
16\end{array}$ & $\begin{array}{l}\text { n.s. } \\
\text { n.s. } \\
\text { n.s. } \\
\text { n.s. } \\
\text { n.s. } \\
\text { n.s. } \\
\text { n.s. }\end{array}$ \\
\hline
\end{tabular}

d.f. = degrees of freedom

$\mathrm{nr}$. = number of observations

n.s. = not significant

s.d. = standard deviation

Exhibit 4-4. Effect of decision support system on profint per period.

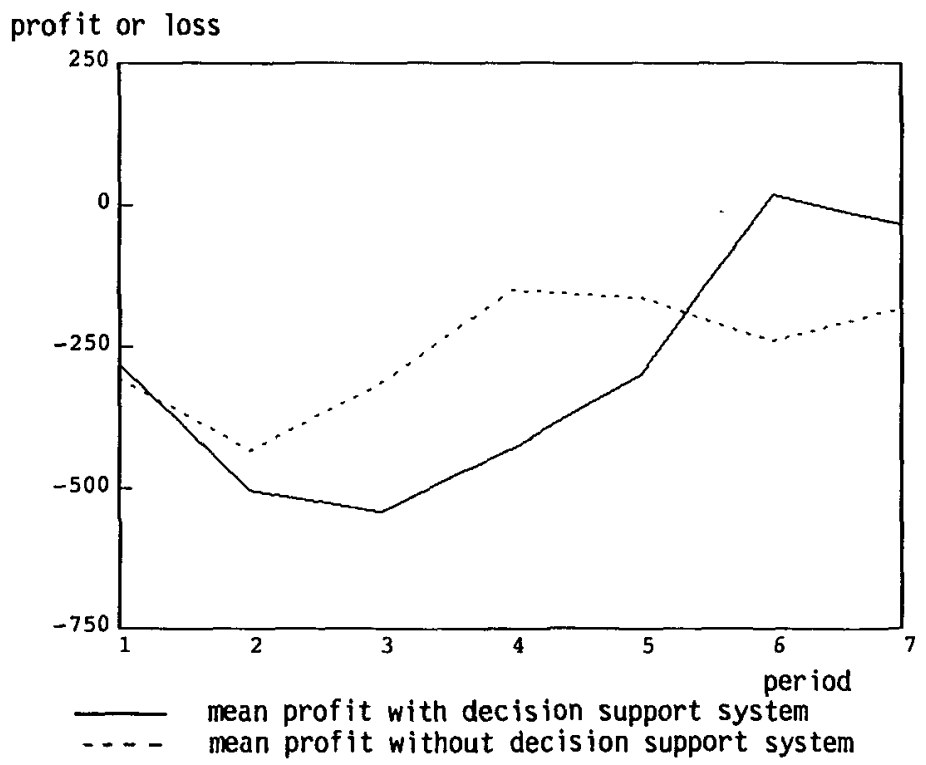

Exhibit 4-5. Graph of the effect of decision support system on profit per period. 
From this analysis we can conclude that in the early periods the non-users outperformed the decision support system users, while in the later periods (6 and 7) the decision support system users outperformed the non-users. However, none of the differences are statistically significant.

These results suggest that a learning effect might be present. In the beginning of the game, all participants have to learn the problem situation. Even though there is time available for practice before the official first period starts, the decision support system users have to learn additionally how to use the decision support system. Since all groups have the same limited amount of time, this might mean that the decision support system users do not have enough time to learn both the problem situation and the decision support system.

To find out, whether there is indeed a long term trend in the company profit, we do a regression analysis with time as the explanatory variable and quarterly profit as the dependent variable. See Kleijnen [1987, p. 151], for a discussion of regression analysis in simulation.

A positive value of the coefficient of the slope indicates that teams are gradually making more profit over time. Several factors might cause this. Obviously, one factor is that the participants make better decisions over time, because they learn how to do it. A second effect, however, is that market conditions nught simply get better or worse leading to all teams on average doing better or worse. There are business cycles in the game, just as there are in the real world. This second effect can be eliminated by comparing groups of users. These results are shown in exhibit 4-6. 


\begin{tabular}{lrr} 
& no DSS & DSS \\
\hline intercept & -523.5 & -846.5 \\
slope (profit) & 33.5 & 67.7 \\
standard deviation (prof $i t)$ & 18.2 & 32.1 \\
\hline
\end{tabular}

Exhibit 4-6. Regression analysis of profit on time.

We can also consider the difference of the slopes. If the coefficient of the decision support system users is higher than the coefficient of the non-users, performance of the decision support system users improves over time more quickly than performance of the non-users. The slopes (coefficient b) are positive for both groups. So, both groups of players do better as time goes by. However, the slope of the decision support system-group is steeper than the slope of the non-decision support system-group. Student's t-tests on the significance of these results were not performed, since the subsequent observations in the 7 time-periods are nbt statistically independent.

These are all results regarding hypothesis 1 . We can conclude from these analyses that the use of a decision support system does not significantly improve the quality of the decisions.

\section{RESULTS CONCERNING DECISION STRATEGY}

Hypothesis 2 concerns the difference in company performance between the teams using a prescribed decision strategy and the teams without such a strategy. The analyses are similar to the ones done on hypothesis 1 . First, we perform a Student's t-test to determine the effect of a well-designed decision strategy on the dependent variables profit and performance score. The results are shown in exhibit 4-7. The number of groups is 
based on period 1.

\begin{tabular}{lcc} 
& no strategy & strategy \\
\hline number of groups & 10 & 13 \\
score & 4.82 & 6.56 \\
standard deviation & 1.30 & 1.26 \\
minimum score & 3.66 & 3.33 \\
maximum score & 7.33 & 7.94
\end{tabular}

Exhibit 4-7. Effect of decision strategy on company performance score.

The calculated value of $t$ is -3.23 , with 21 degrees of freedom. This difference between the scores is significant at level $\mathrm{p}<0.01$.

We also apply the Student's t-test to the second criterion, namely profit; see exhibit 4-8.

\begin{tabular}{lrr} 
& no strategy & strategy \\
\hline number of groups & 10 & 13 \\
score & $-2,787$ & $-1,170$ \\
standard deviation & 2,046 & 1,729 \\
minimum profit & $-6,919$ & $-6,020$ \\
maximum profit & 381 & 929 \\
\hline
\end{tabular}

Exhibit 4-8. Effect of decision strategy on company profit.

The calculated value of $t$ is -2.05 , with 21 degrees of freedom. This difference between the profit is significant at level $\mathrm{p}<$ 0.05 . 


\section{Ch. 4 ANALYSIS OF THE EXPERIMENTAL FINDINGS}

\begin{tabular}{|c|c|c|c|c|c|c|c|}
\hline \multirow[b]{2}{*}{$\begin{array}{l}\text { per- } \\
\text { iod }\end{array}$} & \multicolumn{3}{|c|}{ no strategy } & \multicolumn{2}{|l|}{ strategy } & \multicolumn{2}{|l|}{ difference } \\
\hline & mean & s.d. & $n r$. & mean s.d. & $n r$. & $\begin{array}{l}t- \\
\text { value }\end{array}$ & significance \\
\hline $\begin{array}{l}1 \\
2 \\
3 \\
4 \\
5 \\
6 \\
7\end{array}$ & $\begin{array}{l}-305 \\
-561 \\
-705 \\
-589 \\
-381 \\
-230 \\
-202\end{array}$ & $\begin{array}{l}226 \\
411 \\
760 \\
590 \\
408 \\
536 \\
502\end{array}$ & $\begin{array}{r}10 \\
10 \\
10 \\
10 \\
9 \\
7 \\
6\end{array}$ & $\begin{array}{rl}-285 & 171 \\
-400 & 135 \\
-227 & 218 \\
-72 & 392 \\
-126 & 368 \\
-52 & 447 \\
-60 & 580\end{array}$ & $\begin{array}{l}13 \\
13 \\
13 \\
13 \\
13 \\
12 \\
12\end{array}$ & $\begin{array}{ll}-0.23 & 21 \\
-1.32 & 21 \\
-2.16 & 21 \\
-2.52 & 21 \\
-1.52 & 20 \\
-0.77 & 17 \\
-0.50 & 16\end{array}$ & $\begin{array}{l}\text { n.s. } \\
\text { n.s. } \\
p<0.05 \\
p<0.02 \\
\text { n.s. } \\
\text { n.s. } \\
\text { n.s. }\end{array}$ \\
\hline
\end{tabular}

d.f. = degrees of freedom

$\mathrm{nr} .=$ number of observations

n.s. = not significant

s.d. = standard deviation

Exhibit 4-9. Effect of decision strategy on profit per period.

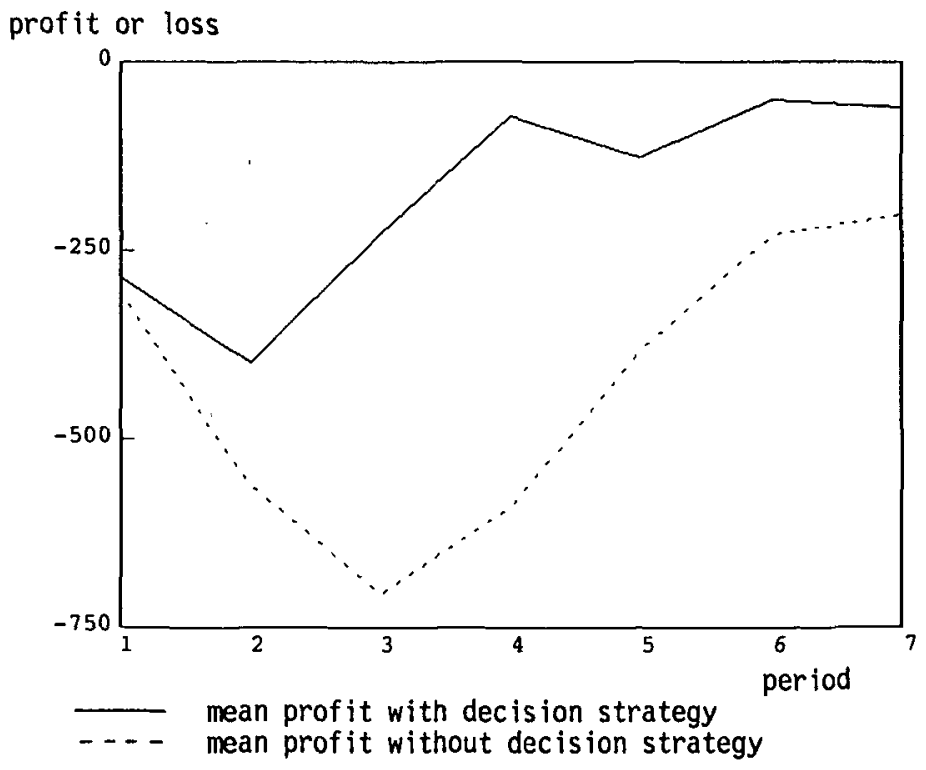

Exhibit 4-10. Graph of the effect of decision strategy on profit per period. 
Next the analysis concentrates on the difference in performance of the teams during each quarter separately. In each period we compare the profits of the teams. In exhibit 4-9 we present the results of this analysis. The results are illustrated in the graph shown in exhibit 4-10.

In the initial periods, 1 and 2, differences are not significant: it takes some time for effects to show their influence.

These are all results regarding hypothesis 2 . We conclude that the use of a decision strategy does significantly improve the quality of the decisions.

RESULTS CONCERNING THE INTERACTION BETWEEN DECISION SUPPORT SYSTEM AND DECISION STRATEGY

As noted by Kleijnen [1987, p. 260], the one factor at a time approach does not enable us to estimate any interactions between factors. In order to determine interaction we need a different approach to the design of the experiment, namely a factorial design, either full or incomplete. Because of the small number of factors (only two) testing all combinations of factor levels is feasible, i.e. we can apply the full factorial design.

First we present the average of the teams per combination (there are $2 \times 2$ combinations); see exhibit 4-11. 


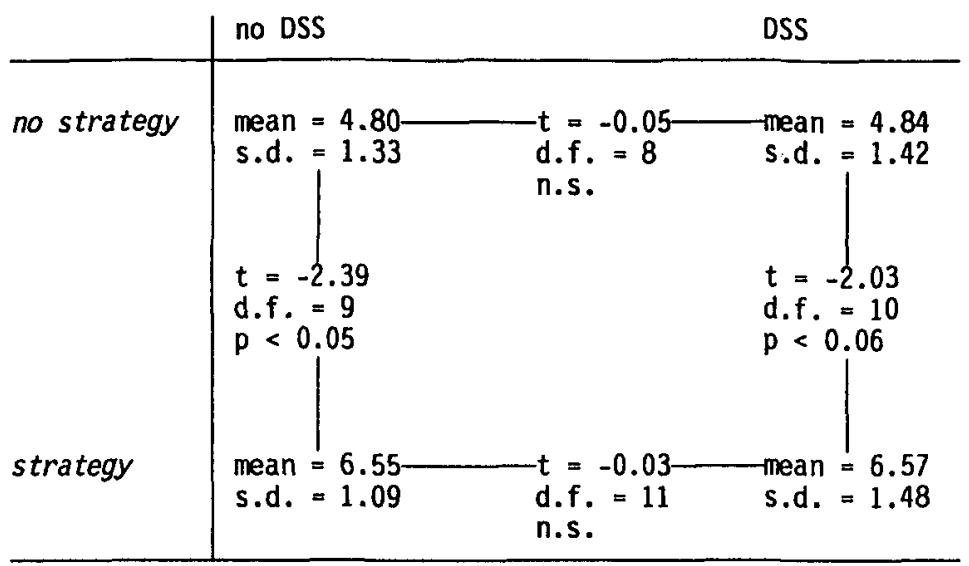

d.f. = degrees of freedom

n.s. = not significant

s.d. = standard deviation

Exhibit 4-11. Performance score under the $2 \times 2$ treatments.

These data suggest that the decision strategy is roughly as effective for decision support system users as for non-users, so that there is no interaction.

A formal test is the analysis of variance (ANOVA). The standard ANOVA procedure cannot handle missing data. As shown in exhibit 4-1, some of the teams did not submit their decisions for the last one, two or three periods. We can decide to either drop the observations on those teams altogether, or to cut off some periods for all teams, or to make a combination of these two. All possibilities gave a similar pattern of results. Here we present the results for the first five periods with 22 out of 23 teams included in the analysis; see exhibit 4-12. 


\begin{tabular}{|l|r|r|r|r|r|}
\cline { 2 - 6 } \multicolumn{1}{c|}{} & \multicolumn{5}{c|}{ period } \\
\cline { 2 - 6 } \multicolumn{1}{c|}{} & 1 & 2 & 3 & 4 & 5 \\
\hline without strategy, without DSS & 5 & 5 & 5 & 5 & 5 \\
\hline without strategy, with DSS & 4 & 4 & 4 & 4 & 4 \\
\hline with strategy, without DSS & 6 & 6 & 6 & 6 & 6 \\
\hline with strategy, with DSS & 7 & 7 & 7 & 7 & 7 \\
\hline \hline total & 22 & 22 & 22 & 22 & 22 \\
\hline
\end{tabular}

Exhibit 4-12. Number of groups under the $2 \times 2$ treatments during 5 periods.

Our experiment is a $2 \times 2 \times 5$ factorial experiment with 'repeated measures' on the last factor. The first factor represents decision support system use: the second factor indicates availability of a prescribed strategy; the third factor refers to the period of play; the criterion is profit per period. The experimental error terms are considered to be normally and independently distributed with zero mean and equal variances.

The statistical formulae for the repeated measures ANOVA are given by Winer [1971, p. 559] and modified for unequal group size, see Winer [1971, p. 599]. These formulas refer to a threefactor experiment with repeated measures on the last two factors. However, our experiment is a three-factor experiment with repeared measures on the last factor. Therefore, in the formulas given by Winer we replace $n \cdot p \cdot q$ by $N=\Sigma n_{1}$ throughout, with 
$\mathbf{n}=$ number of subjects per cell in the case of equal group size

$\mathbf{n}_{1}=$ number of subjects in each of the four cells in the case of unequal group size $(4,5,6$ and 7 respectively in our study)

$N=$ total number of subjects (22)

$\mathrm{p}=$ number of levels of factor decision strategy (2)

$q=$ number of levels of factor decision support system (2)

For example, the degrees of freedom Between subjects (first line in exhibit $4-13$ ) is $n \cdot p \cdot q-1$, replaced by $N-1=21$.

The analysis of variance is given in exhibit 4-13. The significant main effect of the factor 'decision strategy' $(p<0.04)$ indicates that the use of the decision strategy has significant influence on the profits of the teams, as we have already seen in exhibit 4-5.

The F-test of the repeated measures analysis of variance in exhibit 4-13 turns out to be insignificant for the decision support system-treatment. Also, the interaction between decision support system and decision strategy is not significant. 


\begin{tabular}{|c|c|c|}
\hline & Test statistics & \\
\hline $\begin{array}{l}\text { Source of } \\
\text { variation }\end{array}$ & $\begin{array}{l}\text { mean } \\
\text { square }\end{array}$ & $\begin{array}{l}\text { F-value level of } \\
\text { significance }\end{array}$ \\
\hline
\end{tabular}

Between subjects

21

DSS

1

857660.48 n.s.

strategy

1

$9034435.11 p<0.04$

DSS * strategy

1

94420.05 n.s.

[error (between)]

$18 \quad 176950$

Within subjects

88

period

4

116287

2.01 n.s.

period * DSS

4

47310

0.82 n.s.

period * strategy

$4 \quad 133536$

$2.31 p<0.07$

period * DSS * strategy

32962

0.57 n.s.

[error (within)]

72

57833

Total

90

d.f. = degrees of freedom
n.s. $=$ not significant

Exhibit 4-13. Analysis of variance with repeated measures.

The results presented in exhibit 4-13 statistically support the contention that decision support system users do not outperform the non-users, but that decision-makers following the expert strategy do indeed outperform decision-makers who do not know the expert decision strategy. There is significant interaction between decision strategy and period, which agrees 
with exhibit 4-10 (where the two curves are not parallel, see Kleijnen [1987, p. 198-199]).

\section{QUESTIONNAIRE}

Data on the number of alternative courses of action examined during the decision-making are collected from the de-briefingquestionnaire that was distributed to all participants at the end of the experiments. The average number of alternatives examined by the non-users was 1.37 (standard deviation 0.62); it is 2.69 (standard deviation 1.32) for the users, which is significantly different at level $\mathrm{p}<0.01$.

This same questionnaire gives data on user opinions regarding the decision support system. The question asked is: Do you think the decision support system added to the quality of your decisions? The overall opinion on the decision support system is given on a 5-point scale. The results, shown in exhibit 4-14, indicate that the opinion of most decision support system users was that the decision support system actually had a positive infiuence on the quality of the decisions. 
ANALYSIS OF THE EXPERIMENTAL FINDINGS Ch. 4

very negative:

negative:

neutral:

positive:

very positive:

( ${ }^{*}$ represents the opinion of one participant)

Exhibit 4-14. User opinion about the decision support system. 


\section{SUMMARY AND CONCLUSIONS}

\subsection{Summary of Findings}

This dissertation reports the results of an experiment investigating the impact of a decision support system and a decision strategy on the quality of decision-making. A management game was used to provide a laboratory environment in which 90 experienced finance managers acted as decision-makers. This experiment was aimed at comparing the quality of decisions, made either with or without a decision support system and either with or without a decision strategy.

Hypotheses on a positive influence of a decision strategy on the quality of decision-making receive support from the data. However, hypotheses on the impact of a decision support system on quality of decision-making received little or no support from the results of the experiments. Furthermore, the effectiveness of a decision strategy is not affected by the use of a decision support system: no interaction.

The experiment suggests that teams using a decision support system do not perform better than those without. The experiment shows that a decision support system even though its users have a positive opinion about it, does not cause them to make significantly better decisions. Decision quality does improve significantly, though, when decision-makers are guided in the way in which they structure their problem situation. 
The findings of this study are interesting from both an academician's and a practitioner's perspective. For a practitioner it is interesting to note that heavy investments in decision support systems may very well be ill-conceived. Efforts to get control over the process followed to reach decisions may pay off much better. For an academician it is important to know that a decision support system does not necessarily lead to any better decisions. The research into strategies followed by decision-makers looks more promising. This study emphasizes the importance of a better understanding of the decision-making process followed by decision-makers.

As a serendipitous finding this study shows that gaming is an appropriate research approach for investigating decision strategies. 


\subsection{Limitations}

As already elaborated on in section 2.1, the most widely cited criticism of the laboratory approach is that of external validity. Conclusions based on laboratory results may not be generalizable to real-world settings since the laboratory environment is artificial. We tried to mitigate this problem in a number of ways, notably by engaging experienced businessmen as participants.

A similar limitation is that a decision support system, was tested in the experiment: maybe the results do not hold for other decision support systems. However, out of a number of decision support systems initially built, the most appropriate for this particular problem situation was chosen, see section 3.2. A lack of effectiveness of decision support systems was also found in other experiments, see section 2.2. Both our earlier research and work done by other researchers suggest that decision support systems do not improve the quality of decision-making, see section 2.2 .

Finally, we evaluated effectiveness only from the viewpoint of the decision-maker. Actually, the decision support system should also be evaluated from the point of view of the staff-assistant who uses the decision support system generator to develop a specific decision support system. The effectiveness of a decision support system could then be assessed from different angles. 


\subsection{Future Research}

Results of this research provide an excellent basis for further research in several directions.

One direction would be a follow-up study focusing more specifically on the integration between the use of a decision support system and a decision strategy. In our study the decision strategy was presented in the form of a printed flow chart. By embedding a decision strategy into a decision support system the decision-maker could be guided by the system in the way he structures his decision-making process. Such a computer-based method facilitating the adherence to a decision strategy, could then be compared to the non-computerized form, used in this study. By widening the concept of a decision support system, it cocld then even encompass a decision strategy.

Another direction that future research might take is the application of decision strategies in practice. Sol and Van der Ven [1988] conduct research in this area. Their initial results show that problem structuring, instead of computerized support, is the main determinant in increasing decision quality.

Future research might also concentrate on the area of evaluating the relative effectiveness of different decision strategies. Results of the present study revealed a positive relationship between the use of a decision strategy and decision quality, measured by company profits and the composite company performance score described in section 3.7. 
In another follow-up study, causal relations could be explored between the use of a decision strategy and decision quality. By focusing especially on scores based on decision-making process variables and decision-quality variables, the black box of the decision-making process would be opened up even further. The major outcome of such a study would be insights helpful in further improving decision strategies. 


\section{REFERENCES}

AHITUV, N., "A Systematic Approach Toward Assessing the Value of an Information System," MIS Quarterly, (December 1980), 61-75.

ALDAG, R.J. AND D.J. Power, "An Empirical Assessment of Computer-Assisted Decision Analysis," Decision Sciences, 17, (Fall 1986), 572-588.

ALTER, S.L., Decision Support Systems: Current Practices and Continuing Challenges, Addison Wesley Publishing Company, Reading, Mass., 1980.

ANTHONy, R.N., Planning and Control Systems: A Framework for Analysis, Harvard University Graduate School of Business Administration, Boston, Mass., 1965.

ARGYRIS, C., Inner Contradictions of Rigorous Research, Academic Press, New York, 1980.

BEACH, L.R. AND T.R. MITCHELL, "A Contingency Model for the Selection of Decision Strategies," Academy of Management Review, 3, (1978), 439-449.

BENBASAT, I. AND A.S. DEXTER, "Individual Differences in the Use of Decision Support Aids," Joumal of Accounting Research, 20, (Spring 1982), 1-11.

Benbasat, I. AND A.S. DexTer, "An Experimental Evaluation of Graphical and Color-Enhanced Information Presentation," 
Management Science, 31, 11, (1985), 1348-1364.

Benbasat, I. AND A.S. DEXTER, "An Investigation of the Effectiveness of Color and Graphical Information Presentation Under Varying Time Constraints," MIS Quarterly, (March 1986), 59-83.

BENBasat, I., A.S. DEXTER AND P.S. MASUlis, "An Experimental Study of the Human/Computer Interface," Communications of the $A C M, 24,11,(1981), 752-762$.

Benbasat I., A.S. Dexter AND P. TODD, "An Experimental Program Investigating Color-Enhanced and Graphical Information Presentation: An Integration of the Findings," Communications of the ACM, 29, 11, (1986), 1094-1105.

BENBASAT, I. AND R.G. SCHROEDER, "An Experimental Investigation of Some MIS Design Variables," MIS Quarterly, 1, (March 1977), 37-50.

BIGGS, W.D., "Functional Business Games," Simulation \& Games, 18, 2, (June 1987), 242-267.

BONCZEK, R.H., C.W. HolsAPPLE AND A.B. WHINSTON, Foundations of Decision Support Systems, Pergamon Press, New York, 1981.

BoSMAN, A., Een metatheorie over het gedrag van organisaties, Stenfert Kroese B.V., Leiden, the Netherlands, 1977.

Bosman, A. "Relations between Specific Decision Support Systems," in E.R. McLean and H.G. Sol (editors), Decision Support Systems: A Decade in Perspective, Elsevier Science 
Publishers B.V. (North Holland), Amsterdam, the Netherlands, $1986,69-85$.

BOTS, P.W.G. AND H.G. SOL, "An Environment to Support Problem Solving," Decision Support Systems, 3, 3, (1987), 225231.

BOTS, P.W.G., F.D.J. VAN SCHAIK AND H.G. SOL, "An Environment for Testing the Effectiveness of Decision Support Systems," in: Klabbers, J., D. Crookall, H. de Jong and W. Schepers (editors), Simulation-Gaming: On the Improvement of Competence in Dealing with Complexity, Uncertainty and Value Conflicts, Proceedings of the Conference of the International Simulation and Gaming Association, Pergamon Press, Oxford, UK, 1988.

BRookes, C.H.P., "An Automated DSS Requirements Elicitation Model Applied to Non-Repeating Problem Situations," in: Lee, R.M., A.M. McCosh and P. Migliarese (editors), Organizational Decision Support Systems, Proceedings of the IFIP WG 8.3 Working Conference on Organizational Decision Support Systems, North-Holland, Amsterdam, the Netherlands, 1988, 129-138.

BRUSSAARD, B.K. AND P.A. TAS, "Information and Organization Policies in Public Organization," in S.H. Lavington (editor): Information Processing 80, IFIP, North Holland Publishing Company, Amsterdam, the Netherlands, 1980, 821826.

CASIMIR, R.J., "DSS, Information Systems and Management Games," Information and Management, 11, (1987), 123-129. 
CaTS-Barl, W.L., Cognitive Aid and Decision Support Systems: An Empirical Investigation of Three Dimensions, Ph.D. Thesis, University of Wisconsin-Madison, University Microfilms International, No. 8225636, 1982.

CATS-BARIL, W.L. AND G.P. FiUbeR, "Decision Support Systems for Ill-Structured Problems: An Empirical Study," Decision Sciences, 18, (Summer 1987), 350-372.

Chakravarti, D., A.A. MTtchel AND R. StaElin, "Judgment-Based Marketing Decision Models: An Experimental Investigation of the Decision Calculus Approach," Management Science, 25, 3, (1979), 251-262.

CHANDLER, J.S., "A Multiple Criteria Approach for Evaluating Information Systems," MIS Quarterly, (1982), 61-74.

Chervany, N.L. AND G.W. Dickson, "An Experimental Evaluation of Information Overload in a Production Environment," Management Science, 20, 10, (1974), 1335-1344.

COHEN, K.J. AND E. RHENMAN, "The Role of Management Games in Education and Research," Management Science, 10, (1961), 131-166.

COLE, I.W.L. AND I.E. GRIZZLE, "Applications of Multivariate Analysis of Variance to Repeated Measures 'Experiments," Biometrics, 22, (1966), 810-828.

COOK, T.D. AND D.T. CAMPBELL, Quasi-Experimentation: Design and Analysis Issues for Field Settings, Houghton Mifflin, Boston, Mass., 1979. 
COURTNEY, J.F., G. DESANCTIS AND G.M. KASPER, "Continuity in MIS/DSS Laboratory Research: The Case for a Common Gaming Simulator," Decision Sciences, 13, (July 1983), 419-439.

DAVIS, G.B. AND M.H. OLSON, Management Information Systems: Conceptual Foundations, Structure, and Development, McGraw-Hill, New York, Second Edition, 1984.

DeSANCTIS, G. AND G.W. DiCkson, "Computer Graphics as Decision Support Tools for Data Interpretation and Trend Spotting," Proceedings of the Eighteenth Hawaii Intemational Conference on System Sciences, Hollywood, 1985.

DEwEY, J., How We Think, New York, 1910.

Dickson, G.W., J.A. SENN AND N.L. Chervany, "Research in Management Information Systems: The Minnesota Experiments," Management Science, 23, 9, (1977), 913-923.

Dickson, G.W., G. DeSANCTIS AND D.J. MCBRIDE, "Understanding The Effectiveness of Computer Graphics for Decision Support: A Cumulative Experimental Approach," Communications of the ACM, 29, 1, (1986), 40-47.

Dos Santos, B.L. AND M.L. BARIFF, "A Study of User Interface Aids for Model-Oriented Decision Support Systems," Management Science, 34, 4, (1988), 461-468.

ECKEL, N.L., "The Impact of Probabilistic Information on Decision Behavior and Perfermance in an Experimental Game," Decision Sciences, 14, (Fall 1983), 483-502. 
EINHORN, H.J. AND R.M. HOGARTH, "Behavioral Decision Theory: An Empirical Assessment of Decision Making," Decision Sciences, 17, (1986), 79-91.

ElAM, J.J., J.C. HeNDERSON, P.G.W. KeEN, B. KonSYNSKI, C.L. MEADOR, AND D. NESS, $A$ Vision for Decision Support Systems, Unpublished manuscript, 1984.

ELAM, J.J., G.P. HUBER AND M.E. HURT, "An Examination of the DSS Literature (1975-1985)," in E.R. McLean and H.G. Sol (editors), Decision Support Systems: A Decade in Perspective, Elsevier Science Publishers B.V. (North Holland), Amsterdam, the Netherlands, 1986.

FREYENFELD, W.A., Decision Support Systems: An Executive Overview of Interactive Computer-Assisted Decision Making in the UK, NCC Publications, Manchester, England, 1984.

FUERST, W.L. AND P.H. CHENEY, "Factors Affecting the Perceived Utilization of Computer-Based Decision Support Systems in the Oil Industry," Decision Sciences, 13, (1982), 554569.

FUNG-A-YOU, C. AND C.P.J. PloMPEN, Handleiding bij het decision support system voor het spelen van VUMAS, Delft University of Technology, Delft, the Netherlands, 1987.

GALLUPE, R.B., "Experimental Research into Group Decision Support Systems: Practical Issues and Problems," Proceedings of the Nineteenth Annual Hawaii International Conference on System Sciences, Hollywood, 1986. 
GENTRY, J.W., "Group Size and Attitudes Toward the Simulation Experience," Simulation \& Games, 11, 4, (1980), 451-460.

GOLD, S.C. AND T.F. PRAY, "Modeling Market- and Firm-level Demand Functions in Computerized Business Simulations," Simulation \& Games, 15, 3, (September 1984), 346-363.

GORRY, G.A. AND M.S. SCOTT MORTON, "Framework for Management Information Systems," Sloan Management Review, 13, (1971), 55-70.

Goslar, M.D., G.I. Green AND T.H. Hughes, "Decision Support Systems: An Empirical Assessment for Decision Making," Decision Sciences, 17, (Winter 1986), 79-91.

GRAY, P., Guide to IFPS (Interactive Financial Planning System), Second Edition, McGraw-Hill, New York, 1987.

HAMILTON, S. AND N.L. CHERVANY, "Evaluating Information System Effectiveness - Part I: Comparing Evaluation Approaches," MIS Quarterly, (September 1981), 55-68.

HAMILTON, S. AND N.L. CHERvaNY, "Evaluating Information System Effectiveness - Part II: Comparing Evaluator Viewpoints," MIS Quarterly, (December 1981), 79-86.

HAND, H.H. AND H.P. SIMS, "Statistical Evaluation of Complex Gaming Performance," Management Science, 21, 6, (1975), 708717.

HOADLEY, E.D., "Color and its Supplanting Function in Varying Forms of Information Presentation: A Comparative Analysis," Paper presented at the Doctoral Consortium of the 
Seventh Annual Conference on Information Systems, San Diego, California, 1986.

HUBER, G.P., "Cognitive Style as a Basis for MIS and DSS Designs: Much Ado About Nothing?", Management Science, 29, 5, (1983).

JAVELIN Reference Manual, Javelin Software Corporation, 1987.

JOYNER, R. AND K. TUNSTALL, "Computer Augmented Organizational Problem Solving," Management Science, 17, (1970), B212-B225.

KASPER, G.M., A Conceptual Model and Empirical Analysis of Decision Support System Use, Ph.D. Thesis, State University of New York at Buffalo, Buffalo, New York, 1983.

KASPER, G.M., "The Effect of User-Developed DSS Applications on Forecasting Decision-Making Performance in an Experimental Setting," Joumal of Management Information Systems, 2, 2, (1985).

KeEN, P.G.W., "Decision Support Systems: The Next Decade," Decision Support Systems, 3, (1987), 253-265.

KeEN, P.G.W. AND M.S. SCOTT MORTON, Decision Support Systems, An Organizational Perspective, Addison-Wesley Publishing Company, Reading, Mass., 1978.

KeYS, B., "Total Enterprise Business Games," Simulation \& Games, 18, 2, (June 1987), 225-241. 
KING, W.R. AND B.J. EPSTEIN, "Assessing Information System Value: An Experimental Study," Decision Sciences, 14, (1983), 34-45.

KING, W.R. AND J.I. RODRIGUEZ, "Evaluating Management Information Systems," MIS Quarterly, (September 1978), 43-51.

KLEIJNEN, J.P.C., Computer and Profits: Quantifying Financial Benefits of Information, Addison Wesley Publishing Company, Reading, Mass., 1980.

KLEIJNEN, J.P.C., Statistical Tools for Simulation Practitioners, Marcel Dekker, New York, 1987.

KLEIJNEN, J.P.C., "Analyzing Simulation Experiments with Common Random Numbers," Management Science, 34, 1, (1988), 65-74.

KoELEMAN, T., Evaluatie van de effecten van een DSS, Master's Degree Thesis, Delft University of Technology, Delft, the Netherlands, 1988.

LANDRY, M., D. PASCOT AND D. BRIOLAT, "Can DSS Evolve Without Changing Our View of the Concept of 'Problem'?", Decision Support Systems, 1, 1, (1985).

LATOUR, S.A. AND P.W. MINIARD, "The Misuse of Repeated Measures Analysis in Marketing Research," Journal of Marketing Research, XX, (1983), 45-57.

LETTHEISER, R.L., "Computer support for Knowledge Workers: A Review of Laboratory Experiments," Data Base, (Spring 1986), 17-45. 
LOY, S.L., W.E. PRACHT AND J.F. COURTNEY, "Effects of a Graphical Problem-Structuring Aid on Small Group Decision Making," Proceedings of the Twentieth Annual Hawaii International Conference on System Sciences, Hollywood, 1987.

LUCAS, H.C., "Performance in a Complex Management Game," Simulation and Games, 10, 1, (March 1979), 61-74.

LUCAS, H.C. AND N.R. NiELSEN, "The Impact of the Mode of Information Presentation on Learning and Performance," Management Science, 26, 10, (1980), 982-993.

LUSK, E.J. AND M. KeRSNICK, "The Effect of Cognitive Style and Report Format on Task Performance: The MIS Design Consequences," Management Science, 25, 8, (1979), 787-798.

LYONS, N.R., "The Information Game: An Experimental Tool for the Study of Information-Processing Behavior," Simulation \& Games, 13, 1, (March 1982), 86-91.

MATLIN, G., "What is the Value of Investment in Information Systems," MIS Quarterly, (September 1979), 5-34.

MCINTYRE, S.H., "An Experimental Study of the Impact of Judgment-Based Marketing Models," Management Science, 28, 1, (1982), 17-23.

MCLEAN, E.R., "Discussion Comments to: Empirical Studies of Management Information Systems by R.L. Van Horn," Data Base, 5, (Winter 1973), 172-180.

MCLean, E.R. AND H.G. SOL (editors), Decision Support Systems: A Decade in Perspective, Elsevier Science Publishers B.V. (North Holland), Amsterdam, the Netherlands, 1986. 
MCLEOD, R. AND J.W. JONES, "Information System Components Utilized by Senior-Level Executives," Proceedings of the Nineteenth Annual Hawaii International Conference on System Sciences, Hollywood, 1986.

MeIer, R.C., W.T. Newell AND H.L. PaZer, Simulation in Business and Economics, Prentice-Hall, Englewood Cliffs, N.J., 1969.

MILleR, D.W. AND M.K. STARR, Executive Decisions and Operations Research, Prentice-Hall, Englewood Cliffs, N.J., 1960.

MintzBerG, H., D. RAISINGHANI AND A. Théorêt, "The Structure of "Unstructured" Decision Processes," Administrative Science Quarterly, 21, (1976), 246-275.

MrTroff, I.I., F. BETZ, L.R. PONDY AND F. SAGASTI, "On Managing Science in the System Age: Two Schemes for the Study of Science as a Whole Systems Phenomenon," TIMS Interfaces, 4, 3, (May 1974), 46-58.

MOLENGRAAF, P.C., Evaluatie van de effecten van een decision support system; System $W$ in acht organisaties, Master's Degree Thesis, Delft University of Technology, Delft, the Netherlands, 1988.

Motiwalla, J. AND F.Y.K. Pheng, "Decision Effectiveness and Information Use: Effects of Cognitive Style, Complexity, and Stress," in: M. Ginzberg and C.A. Ross (editors), Proceedings of the Third International Conference on Information Systems, ACM, Baltimore, (1982), 137-149. 
NEWELL, A., "Heuristic Programming: Ill-Structured Problems," in: Avonofsky, J. (editor): Progress in OR, 3, 1969.

NILSSON, N.J., Problem-Solving Methods in Artificial Intelligence, McGraw-Hill, New York, 1971.

NORRIS, D.R., "External Validity of Business Games," Simulation \& Games, 17, 4, (1986), 447-459.

Partridge, S.E., D. SCulli, S.H. WONG, "Designing Management Games for Production Management Training," Simulation \& Games, 15, 3, (September 1984), 328-345.

PiePTEA, D.R. AND E.E. ANDERson, "Price and Value of Decision Support Systems," MIS Quarterly, 11, 4, (1987), 515526, also: Proceedings of the Nineteenth Annual Hawaii International Conference on System Sciences, 1986.

PRACHT, W.E. AND J.F. COURTNEY, "A Visual User Interface for Capturing Mental Models in Model Management Systems," Proceedings of the Nineteenth Annual Hawaii International Conference on System Sciences, 1986.

RADOSINSKI, E. AND L. SZCZUROWSKI, "Computer Simulation Applied to Education in a Firm's Finances: The Computerized Financial Games," Simulation \& Games, 16, 4, (December 1985), 417-428.

REIMANN, B.C. AND A.D. WARREN, "User-Oriented Criteria for the Selection of DSS Software," Communications of the $A C M, 28,2$, (1985), 166-179. 
REMUS, W.E., "An Empirical Investigation of the Impact of Graphical and Tabular Data Presentations on Decision Making," Management Science, 30, 5, (1984), 533-542.

REMUS, W.E. AND J.E. KoTtEMANN, "Semi-Structured Recurring Decisions: An Experimental Study of Decision Making Models and Some Suggestions for DSS," MIS Quarterly, (June 1987), 233-243.

SANDERS, G.L. AND J.F. COURTNEY, "A Field Study of Organizational Factors Influencing DSS Success," MIS Quarterly, (March 1985), 77-93.

SCHELlENBERGER, R., G. BOSEMAN AND B.T. SCHELLENBERGER, A Dynamic Management Simulator with Decision Support System, John Wiley \& Sons, New York, 1982.

SCOTT, C.R. AND A.J. STRICKLAND III, Tempomatic $N, A$ Management Simulation, Houghton Mifflin, Boston, 1984.

Shane, B. M. GOUl AND F. TONGE, "Knowledge Based Decision Support Systems in Strategic Planning Decision: An Empirical Study," Proceedings of the Nineteenth Annual Hawaii International Conference on System Sciences, Hollywood, 1986.

SHANNON, R.E., Systems Simulation: The Art and Science, Prentice-Hall, Englewood Cliffs, N.J., 1975.

SHARDA, R., S.H. BARR AND J.C. MCDONNELl, "Decision Support System Effectiveness: A Review and an Empirical Test," Management Science, 34, 2, (1988), 139-159.

SHARFF, T., Weighted Ranking by Levels, Studiecentrum NOVI, Amsterdam, the Netherlands, 1969. 
SHUBIK, M., Games for Society, Business and War, Towards a Theory of Gaming, Elsevier Scientific Publishing Company, Amsterdam, the Netherlands, 1975.

Simon, H.A., The New Science of Management Decision, Harper and Brothers, New York, 1960.

SLAGle, J.R., Artificial Intelligence: The Heuristic Programming Approach, McGraw-Hill, New York, 1971.

SoL, H.G., Simulation in Information Systems Development, $\mathrm{Ph} . \mathrm{D}$. Thesis, University of Groningen, Groningen, the Netherlands, 1982.

Sol, H.G., "Aggregating Data for Decision Support," Decision Support Systems, 1, 2, (1985), 111-121.

Sol, H.G., "Conflicting Experiences with -DSS," Decision Support Systems, 3, (1987), 203-211.

SOL, H.G. AND M.B.M. VAN DER VEN, "Integrating GDSS in the Organization: The Case of a GDSS for International Transfer Pricing", in Lee, R.M., A.M. McCosh, and P. Migliarese (editors), Organizational Decision Support Systems, Proceedings of the IFIP WG 8.3 Working Conference on Organizational Decision Support Systems, North-Holland, Amsterdam, the Netherlands, 1988, 15-30.

SOL, H.G. AND A.A. VERRIJN STUART, "Information Planning for Personal Computing: Putting the User in Profile", in Jeffery, R.: Proceedings of the Joint International Symposium Information Systems, Australian Computer Society, Sydney, Australia, 1988. 
SPRaGue, R.H., "Conceptual Description of a Financial Planning Model for Commercial Banks," Decision Sciences, 2, 1, (1971), 66-80.

SPRAGUE, R.H., "A Framework for the Development of Decision Support Systems", MIS Quarterly, 4, 4, (December 1980), 1-26.

SPRAGUE, R.H., "DSS in Context", in: E.R. McLean and H.G. Sol (editors), Decision Support Systems: $A$ Decade in Perspective, Elsevier Science Publishers B.V. (North Holland), Amsterdam, the Netherlands, 1986, 19-24.

SPRAGUe, R.H. JR. AND E.D. CARLSON, Building Effective Decision Support Systems, Prentice-Hall, Englewood Cliffs, N.J., 1982.

SPRAGUE, R.H. JR. AND B.C. MCNURLIN, Information Systems Management in Practice, Prentice-Hall, Englewood Cliffs, N.J., 1986.

SRINIVASAN, A., "Alternative Measures of System Effectiveness: Associations and Implications," MIS Quarterly, (September 1985), 243-253.

STANISLAW, H., "Tests of Computer Simulation Validity," Simulation \& Games, 17, 2, (June 1986), 173-191.

SWAAB-DEKKER, P.M., Evaluatie van de Beslissingsondersteunend-Systeem Generatoren Javelin, Micro-FCS en IFPS-Personal (Evaluation of the Decision Support System Generators Javelin, Micro-FCS and IFPS-Personal), Master's Degree Thesis, Delft University of Technology, Delft, the Netherlands, 1987. 
Thierauf, R.J., Decision Support Systems for Effective Planning and Control: A Case Study Approach, Prentice-Hall, Englewood Cliffs, N.J., 1982.

Uhr, L., Pattern Recognition, Learning and Thought, PrenticeHall, Englewood Cliffs, N.J., 1973.

UMANATH, N.S. AND R.W. SCAMELL, "An Experimental Evaluation of the Impact of Data Display Format on Recall Performance," Communications of the ACM, 31, 5, (1988), 562570.

VAN HORN, R.L., "Empirical Studies of Management Information Systems," Data Base, 5, (Winter 1973), 172-180.

VAN SCHAIK, F.D.J., Een Bedrijfsspel voor Beslissingsondersteuning (A Business Game for Decision Support), Master's Degree Thesis, Catholic University Brabant, Tilburg, the Netherlands, 1984.

VAN SCHAIK, F.D.J., "Een Laboratorium voor Informatiesystemen (A Laboratory for Informationsystems)," in A.J. van 't Klooster and J.A.M. Oonincx (editors): Leerboek Informatiesystemen, Samsom Uitgeverij, Alphen aan den Rijn, the Netherlands, 1986.

VAN SCHAIK, F.D.J., Effectiveness of Decision Support Systems, Paper presented at the Doctoral Consortium of the Seventh Annual Conference on Information Systems, San Diego, California, 1986.

VAN SCHAIK, F.D.J., "Effectiveness of Decision Support Systems," Data Base, 18, 3, (1987), 58-59. 
VAN SCHAIK, F.D.J., Beschrijving van een Decision Support System voor het spelen van VUMAS (Description of a Decision Support System for playing VUMAS), Delft University of Technology, Delft, the Netherlands, 1988.

VAN SCHAIK, F.D.J. AND H.G. SOL, "Effectiveness of environments for supporting decision-making: The case of equation models versus process models," in Stimulerende Informatica, Proceedings of the NGI-SION Symposium 4, Utrecht, the Netherlands, 1986.

Volonino, L., C.C. SEKAR AND R. RAMESH, "Decision Quality and Information Load," Proceedings of the Twentieth Annual Hawaii International Conference on System Sciences, Hollywood, 1987.

VON NeUmanN, J. AND O. MORGENSTERn, The Theory of Games and Economic Behavior, Princeton University Press, Princeton, N.J., 1953.

VUMAS Users Manual, Rematch B.V., Amsterdam, the Netherlands, 1987.

WeBER, E.S., "Systems to Think With: A Response to "A Vision for Decision Support Systems", Joumal of Management Information Systems, II, 4, (1986), 85-97.

WINER, B.J., Statistical Principles in Experimental Design, McGraw-Hill, New York, Second Edition, 1971.

WITTE, E., "Field Research on Complex Decision-Making Processes-The Phase Theorem," International Studies of Management and Organization, (1972), 156-182. 
References

WOLFE, J. AND C.R. ROBERTS, "The External Validity of a Business Management Game: A Five-Year Longitudinal Study," Simulation \& Games, 17, 1, (March 1986), 45-59. 


\section{Samenvatting in het Nederlands}

\section{EFFECTIVITEIT VAN BESLISSINGSONDERSTEUNENDE SYSTEMEN}

Dit proefschrift brengt verslag uit van een onderzoek naar de effectiviteit van de ondersteuning van besluitvorming door managers. Onderzocht is of in slecht-gestructureerde probleemsituaties met ondersteuning betere beslissingen genomen worden dan zonder.

Als ondersteuning is enerzijds gebruik gemaakt van een beslissingsondersteunend systeem, dat wil zeggen een computersysteem speciaal gericht op het ondersteunen van management beslissingen. Anderzijds is de invloed onderzocht van een zogenaamde beslissingsstrategie: een voorschrift welke stappen gezet dienen te worden in een beslissingsproces.

Als onderzoeksaanpak is het laboratorium-onderzoek gehanteerd. Vergeleken met andere methoden van empirisch onderzoek naar informatiesystemen blijkt de laboratoriumaanpak grote voordelen te hebben, met name voor wat betreft het beheersen van vertroebelende factoren.

Een management game is gebruikt als laboratorium-omgeving, waarin 90 ervaren financiële managers optraden als beslissers. Er werd een experiment uitgevoerd met het doel een vergelijking te maken van de kwaliteit van beslissingen, gemaakt met en zonder beslissingsondersteunend systeem en met en zonder beslissingsstrategie.

Als management game voor het uitvoeren van de experimenten is gewerkt met VUMAS. Het is een simulatie van het leiden van een produktie-onderneming en behelst aspecten van 
marketing, produktie, inkoop, personeelsmanagem.ent, en financieel management. Gedurende zeven ronden worden steeds 37 beslissingen genomen. Elk team concurreert tegen vier tegenstanders.

Het beslissingsondersteunende systeem is een systeem dat het gemakkelijk maakt historische gegevens op te vragen, grafieken te maken, voorspellingen te doen en toekomstige scenarios door te rekenen, dat wil zeggen "what-if"-analyses te doen.

De beslissingsstrategie schrijft voor welke stappen gezet dienen te worden bij het nemen van beslissingen. Deze strategie is ontworpen door een expert. Het brengt structuur aan in het beslissingsproces, maar het geeft geen concrete aanwijzingen welke beslissingen het best genomen kunnen worden.

De deelnemers aan het experiment zijn 90 mensen uit de praktijk, met functies als controller en hoofd financieeleconomische afdeling. $\mathrm{Zij}$ volgden een cursus financieeladministratief management. Als onderdeel van deze cursus leerden zij werken met beslissingsondersteunende systemen en namen zij deel aan het experiment.

Voor de uitvoering van het experiment werden de deelnemers ingedeeld in teams van 3 aे 4 leden. Zo ontstonden 23 teams, die weer werden ingedeeld in 4 groepen. De eerste groep speelde het management game zonder een beslissingsondersteunend systeem en zonder beslissingsstrategie. De tweede groep met beslissingsondersteunend systeem, maar zonder beslissingsstrategie. De derde groep zonder beslissingsondersteunend systeem, maar wel volgens de beslissingsstrategie. De vierde groep, tot slot, nam beslissingen met behulp van het beslissingsondersteunende systeem en volgens de beslissingsstrategie. Door het toeval te laten bepalen 
Samenvatting

welk team in welke groep speelt, kunnen de resultaten tussen de groepen goed worden vergeleken.

Om te beoordelen hoe goed de beslissingen zijn van de teams wordt gekeken naar de bedrijfsresultaten van de gesimuleerde onderneming. Behalve naar de winst wordt ook gekeken naar een totaalscore, waarop naast winst maatstaven invloed hebben, zoals tevredenheid van het personeel, aantal stakingen, overschot of tekort aan produkten, en failissement.

Hypotheses met betrekking tot een positieve invloed van een beslissingsstrategie op de kwaliteit van beslissingen worden ondersteund door de experimentele gegevens. Echter, hypotheses met betrekking tot een positieve invloed van een beslissingsondersteunend systeem worden niet ondersteund. Verder blijkt dat een beslissingsondersteunend systeem niet van invloed is op de effectiviteit van de beslissingsstrategie, dat wil zeggen er is geen interactie.

De uitkomsten van de experimenten geven aan dat beslissers die gebruik maken van een beslissingsondersteunend systeem geen betere beslissingen nemen dan beslissers die zonder zo'n systeem werken. Dit ondanks een overwegend positieve mening van de gebruikers over het beslissingsondersteunende systeem.

Door echter de beslisser te helpen met het structureren van de beslissingssituatie waarin hij zich bevindt kan wel een duidelijke verbetering van zijn beslissingen worden bereikt. Wanneer de beslisser een beslissingsstrategie wordt aangereikt, die ontworpen is door een expert op het betreffende gebied, dan leidt dat tot een significant hogere kwaliteit van zijn beslissingen. 
De betekenis van deze onderzoeksuitkomsten voor de praktijk is dat het verbeteren van besluitvorming meer gediend is met een verdere structurering van het beslissingsproces dan met beslissingsondersteunende systemen. 


\section{DANKWOORD}

Mijn dank gaat in de eerste plaats uit naar Prof.Dr. H.G. Sol.

Zijn enorme inzet en professionaliteit hebben het voor mij tot een groot genoegen gemaakt onder zijn leiding onderzoek te verrichten en onderwijs te geven. Gedurende de periode van vier jaar, dat ik aan de Technische Universiteit Delft verbonden ben geweest, heeft hij een vakgroep Informatiesystemen tot ontwikkeling gebracht, waar een zeer positieve, op productief onderzoek gerichte sfeer heerst. Zijn intensieve begeleiding is voor $\mathrm{mij}$ een enorme stimulans geweest.

Ik dank Drs. P.W.G. Bots voor de plezierige samenwerking bij het verzorgen van het college Beslissingsondersteunende Systemen. Tijdens dit college is de basis gelegd voor de experimenten beschreven in dit proefschrift.

Drs. M.B.M. van der Ven dank ik voor de vele opbouwende discussies, die wij hebben gevoerd over ons promotieonderzoek.

Verder dank ik al mijn overige collega's van de vakgroep Informatiesystemen, in het bijzonder de leden van de Kongsi, voor de inspirerende omgeving, die zij voor mij hebben gevormd.

Prof.Dr. J.P.C. Kleijnen is degene geweest die mij, reeds in 1980, heeft gewezen op de mcgelijkheid de effectiviteit van 
beslissingsondersteunende systemen te onderzoeken met behulp van management games.

De heren Dr.Ir. T.J. van den Akker, Drs. L. de Man, en Drs. A. Klaassen van Rematch B.V. te Amsterdam hebben welwillend het VUMAS management game beschikbaar gesteld en ondersteuning gegeven bij het gebruik daarvan.

De heer J.A.W. Seijsener, directeur van KTO Opleidingen, heeft bijgedragen aan de organisatorische voorbereiding van de experimenten en de heren Drs. B.W. van der Togt en J. van Nieuwenhuizen hebben als docenten aan de experimenten meegewerkt.

De heren Ir. D.J. Rempt, C. Fung-A-Youu, J. van Dijke en C.P.J. Plompen hebben als student-ässistent gewerkt aan het ontwikkelen van de programmatuur en het organiseren van de experimenten.

Tot slot dank ik allen, die als deelnemers aan het management game bij dit onderzoek betrokken zijn geweest. Hun enthousiasme maakte het begeleiden van het spel voor mij steeds weer tot een genoegen. 


\section{CURRICULUM VITAE}

De schrijver van dit proefschrift werd op 11 oktober 1956 geboren te Yerseke. Van 1969 tot 1975 bezocht hij het Chr. Lyceum voor Zeeland te Goes, waar hij in 1975 het eindexamen Gymnasium- $\beta$ behaalde. Vanaf 1975 studecrde hij Econometrie aan de Katholieke Universiteit Brabant (KUB) en vanaf 1980 Bestuurlijke Informatiekunde aan de Rijksuniversiteit Groningen (RUG). In 1982 behaalde hij het doctoraal-examen Bestuurlijke Informatiekunde (Administratief-Organisatorische Variant) aan de Economische Faculteit van de Rijksuniversiteit Groningen. In 1984 volgde het doctoraal-examen Bedrijfseconometrie cum laude aan de Katholieke Universiteit Brabant te Tilburg (afstudeerhoogleraar Prof. Dr. J.P.C. Kleijnen).

Hij gaf onderwijs in Statistiek en Administratieve Automatisering aan de Koninklijke Militaire Academie (KMA) te Breda gedurende 1983 en 1984. Hem werd de Academie Medaille verleend als blijk van waardering voor verdiensten ten aanzien van de KMA. Het accountantsexamen behaalde hij in 1985 aan de Rijksuniversiteit Groningen. Sindsdien is hij lid van het Nederlands Instituut van Registeraccountants (NIVRA) en voert hij een zelfstandige accountantspraktijk.

Gedurende de periode 1984 - 1988 was hij als promovendus verbonden aan de Vakgroep Informatiesystemen van de Faculteit der Technische Wiskunde en Informatica van de Technische Universiteit Delft. Hij heeft daar het college Beslissingsondersteunende Systemen verzorgd. $\mathrm{Hij}$ heeft voordrachten gehouden op conferenties en seminars in Nederland, Engeland en de Verenigde Staten. In 1986 nam hij deel aan het doctoral consortium van de International Conference on Information Systems te San Diego, Californië. $\mathrm{Hij}$ heeft artikelen gepubliceerd in diverse nationale en internationale tijdschriften. Het NIVRA kende hem in 1986 de Sinninghe-Damste-Prijs toe voor zijn artikel "Een Laboratorium voor Informatiesystemen". 


\section{INDEX}

Analysis of variance (ANOVA) 121

Analytic procedures 5

Bounded rationality 5

Brainstorming phase 7

Business game 44

Case study 41

Case-study/textbook problem approach 43

Choice phase 7

Co-ordination 37

Cognitive

constraints 38

emphasis 24

limitation 5

style 54

Complexity 47

Components 26

Composite company performance score 108

Conceptual model 10

Conceptualization 10

Consistency check 10

Correspondence check 10

Data subsystem 26

Decision 8, 24

Decision strategy 2, 16, 86

Decision support environment 40

Decision support system 21, 75

bandwagon 25

concept 23

generator 26 


\section{movement 24}

Decision support tool 26

Decision-maker 4

Decision-making 4

paradigm 5

process 6

Dependent variable 103

Design phase 7

Development method 19-21

Dilemmas 36

Effectiveness 16

Efficiency 16

Empirical model 10

Equation model 86

Evaluation 103

Experimental design 92

Experimental treatment 92

External validity 48

Face validity 48

Factor 92

Factorial design 95

Field study 41

Field test 42

Free type 57

Game 44, 65

Gaming 43

Homo economicus 4

Ill-structured 13

Implementation 7

Independent variable 92, 103

Information system 18, 49

Information systems paradigm 49

Initialization 73

Integration 130

Intelligence phase 7

Interaction 120 
Index

Internal validity 45

Javelin 76

Knowledge system 28

Laboratory study 42

Language system 28

Learning effect 116

Management control 69

Management game 44

Management Information Systems 20

Model of decision-making process 6

Model subsystem 27

Non-programmed problem 13

Objective rationality 4,5

Operational control 69

Optimal alternative 5

Optimization model 31

Paradigm

decision-making 5

information systems 49

Parametrization 58

Phantom companies 101

Plausibility 48

Portability 59

Problem 4

Problem decomposition tools 32

Problem specification 10

Problem-processing system 28

Problem-solving 6

Procedural rationality 5

Procedures 100

Process model 86

Programmed problem 13

Prototype 37

Pure-machine simulation 43

Randomization 94

Real system 10, 49 
Recursion principle 51

Repeated measures design 97

Rigid type 57

Satisficing alternative 5

Selection 76

Simulation 43

Solution 10

Specific decision support system 26

Spreadsheets 80

Strategic planning 69

Structuredness of a problem 13

Structuring a problem 15

Subject Population 98

Subproblems 16

Support 24

System 24

System theoretic basis 49

Transaction Processing Systems 18

Treatments 92

Type I and type II work 33

User-system interface 27

Validation 47

Verisimilitude 48

VUMAS 65

War game 44, 57

Well-structured 13

What-if analysis 31 


\section{STELLINGEN}

behorende bij het proefschrift van

F.D.J. van Schaik

Effectiveness of Decision Support Systems 
1. Beslissingsondersteunende systemen worden soms gelijkgesteld met gebruiksvriendelijke operations research. Operations research moet echter beschouwd worden als slechts eén van de toeleverende disciplines aan de ontwikkeling van beslissingsondersteunende systemen.

2. Bedrijfsspelen dienen een belangrijker plaats te gaan innemen in onderwijs en training. De toepassing van bedrijfsspelen biedt effectieve mogelijkheden voor kennisoverdracht en opdoen van ervaring.

3. Bij de ontwikkeling van informatiesystemen wordt vaak verwacht dat het systeem wordt aangepast aan de bestaande organisatie. Een argument daartegen kan zijn: Een geautomatiseerde chaos is nog steeds een chaos.

4. Een computerbestand is geen geschrift. Het vervalsen van gegevens in een computerbestand kan dan ook niet gekwalificeerd worden als valsheid in geschrifte.

5. Het toevoegen aan een proefschrift van stellingen die geen betrekking hebben op het onderwerp van het proefschrift dient om aan te tonen dat universiteiten universele mensen opleiden. Het is afkeurenswaardig dit gebruik af te schaffen. 
6. Binnen de universitaire wereld dient een dissertatie niet beschouwd te worden als een levenswerk maar als een toelatingsbewijs.

7. De file-problematiek kan aanzienlijk worden verlicht door een beleid gericht op "woon-waar-je-werkt". Een element daarvan kan zijn het afschaffen van de overdrachtsbelasting en van de aftrekbaarheid van de kosten van woonwerkverkeer.

8. Het inkomens-afhankelijk maken van overheidsdiensten, zoals lessen van muziekscholen, leidt tot moeilijk overzienbare nivelleringseffecten. Voor de overzichtelijkheid is het te prefereren nivellering alleen via de inkomstenbelasting te laten plaatsvinden.

9. Om te bevorderen dat zowel mannen als vrouwen in het arbeidsproces worden opgenomen is het aan te bevelen dat de kosten van crèche en kinderoppas fiscaal aftrekbaar worden.

10. Het lage percentage ingenieurs en meesters in de rechten dat promoveert rechtvaardigt dat zij niet betiteld worden als Weledelgeleerd. 